\title{
REDES NEURAIS ARTIFICIAIS APLICADAS A PROTEÇÃO DE SISTEMAS ELÉTRICOS DE POTÊNCIA
}

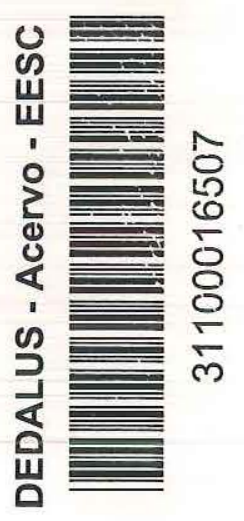

DA VID CALHAU JORGE

Dissertação apresentada à Escola de Engenharia de São

Carlos, da Universidade de São Paulo, como parte dos requisitos para obtenção do Título de Mestre em Engenharia Elétrica

ORIENTADOR: Prof. Dr. Denis Vinicius Coury

São Carlos

1997 


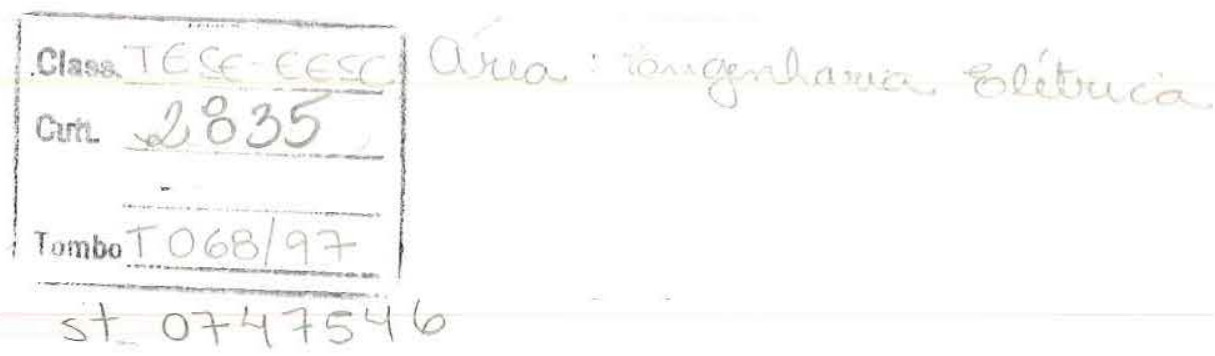

Ficha catalográfica preparada pela Seçăo de Tratamento da Informaçăo do Serviço de Biblioteca - EESC-USP

Jorge, David Calhau
J82r Redes Neurais Artificiais aplicadas a proteção de sistemas elétricos de potência / David Calhau Jorge. -- São Carlos, 1997.

Dissertação (Mestrado). -- Escola de Engenharia de São Carlos-Universidade de São Paulo, 1997. Área: Engenharia Elétrica Orientador: Prof. Dr. Denis Vinicius Coury

1. Sistemas de potência. 2. Relés de distância. 3. Proteção de sistemas elétricos de potência.

4. Redes Neurais Artificiais. I. Título 


\section{FOLHA DE APROVACÃO}

Dissertação defendida e aprovada em 21-3-1997 pela Comissão Julgadora:

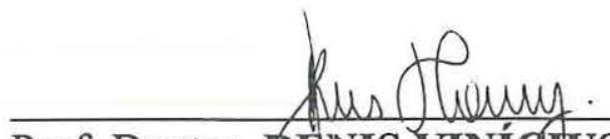

Prof. Doutor DEINIS VINÍCIUS COURY (Orientador)

(Escola de Engenharia de São Carlos - Universidade de São Paulo)

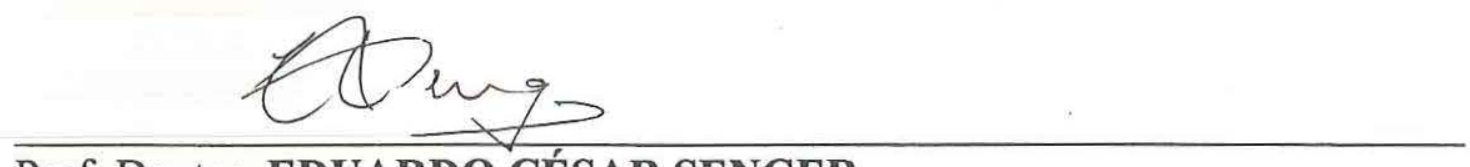

Prof. Doutor EDUARDO CÉSAR SENGER

(Escola Politécnica - Universidade de São Paulo)

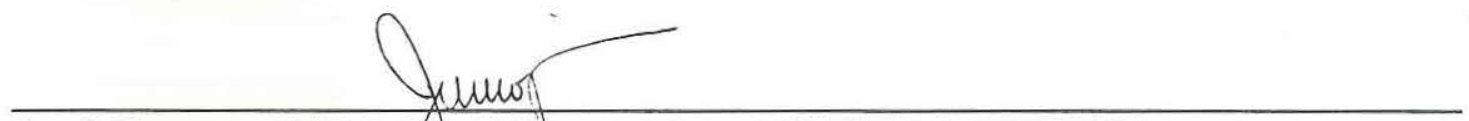

Prof. Doutor CARLOS ALBERTO DE CASTRO JUNIOR (Universidade de Campinas - UNICAMP)

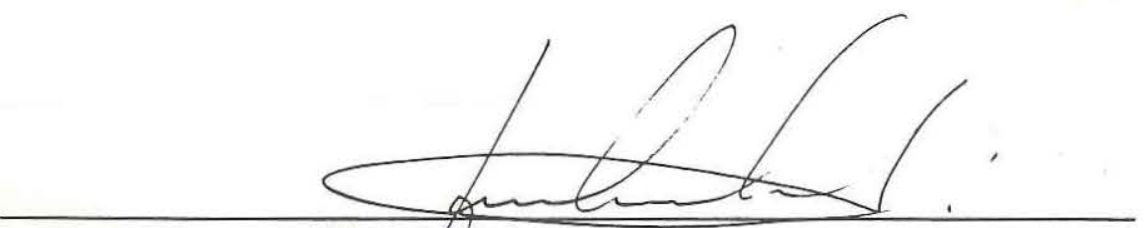

Prof. Doutor. GERAIDO ROBERTO M. DA COSTA Coordenador da Área de Engenharia Elétrica

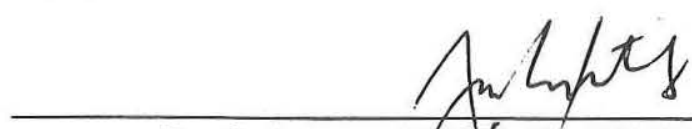

Prof. Assoc. JOSÉ CARLOS A. CINTRA Presidente da Comissão de Pós-Graduação 
A minha família, sem a qual este trabalho não seria possível. 


\section{AGRADECIMENTOS}

A Deus por ter permitido e me auxiliado na execução deste trabalho.

Ao meu orientador Prof. Dr. Denis Vinicius Coury, cuja orientação e amizade foram imprescindíveis para conclusão deste trabalho.

A CAPES pelo apoio financeiro dispensado para a realização de meu trabalho.

Aos colegas, professores e funcionários do Departamento de Engenharia Elétrica da EESC/USP por todo auxílio e amizade. 
SUMÁRIO

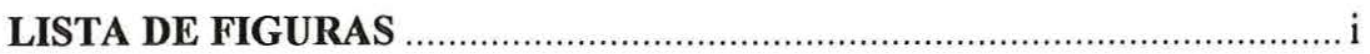

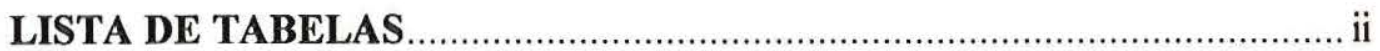

LISTA DE ABREVIATURAS E SIGLAS ............................................. iv

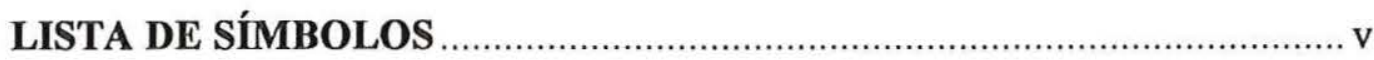

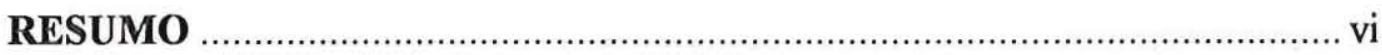

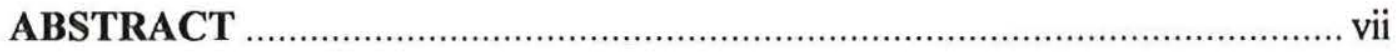

1-INTRODUÇÃO

1.1-Faltas em Sistemas Elétricos de Potência ...................................................... 13

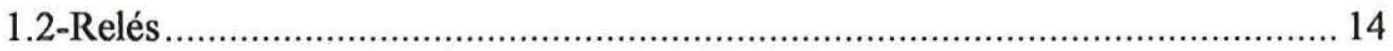

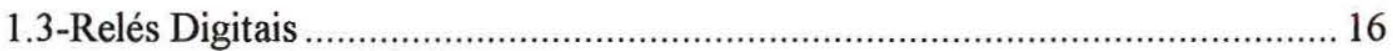

1.4-Relés Digitais de Distância ....................................................................... 20

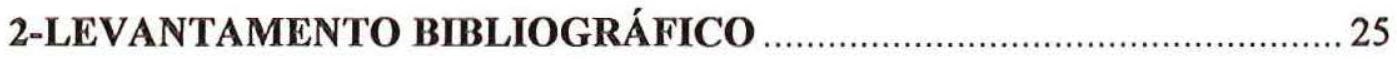

3-REDES NEURAIS ARTIFICIAIS E SUA APLICAÇÃO NA PROTEÇÃO DE SISTEMAS ELÉTRICOS DE POTÊNCIA …………........... 32

3.1-Conceitos Biológicos Básicos do Neurônio ……………………………......... 32

3.2-As Vantagens da Implementação de uma Rede Neural Artificial ...................... 34

3.3- Redes Neurais Artificiais e o Reconhecimento de Padrões .............................. 37

3.4-Modelos de Redes Neurais Artificiais de Multicamadas ................................... 38

3.5-O Método de "Back-propagation"................................................................. 40

3.6-Redes Neurais Artificiais Utilizando o Método de "Back-Propagation"

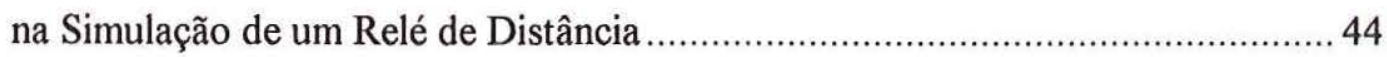

3.7-"Hardware" Necessário para Implementação do Relé Proposto ....................... 46 
4.1-Descrição do Problema e Parâmetros das Arquiteturas das RNA's. 48

4.2-Primeira Arquitetura de RNA, Utilizando Modelo de uma LT com a Variação Apenas da Distância do Ponto da Falta

4.3-Segunda Arquitetura de RNA, Utilizando Modelos de LT com a Variação de Rf e Distância da Falta na LT Considerada 58

4.4-Terceira Arquitetura de RNA, Utilizando Modelo com a Variação da Resistência e Distância de Falta, Ângulo de Incidência da Mesma e da Condição de Operação Presente na LT

ANEXO - Publicações Provenientes deste Trabalho. 83 REFERÊNCIAS BIBLIOGRÁFICAS 84 APÊNDICE I - Programa para Simulação de Linhas de Transmissão em Condições Faltosas - TEER 88 APÊNDICE II - Transformada Discreta de Fourier 94 


\section{LISTA DE FIGURAS}

Figura 01-Representação simples de um relé

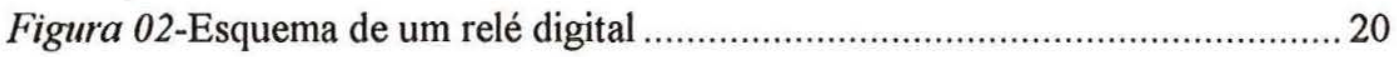

Figura 03-Linha com uma falta na zona de proteção.[2] ................................... 22

Figura 04-Diagrama esquemático de um neurônio humano.................................... 33

Figura 05-Arquitetura de uma Rede Neural Artificial ..................................... 38

Figura 06-Uma arquitetura de RNA utilizada como relé de distância ................... 44

Figura 07-Diagrama de blocos de um relé de distância baseado em RNA ............ 47

Figura 08-Modelo da Linha de Transmissão.......................................................... 49

Figura 09-Arquitetura da RNA, com dados de treinamento incluindo apenas

a variação da distância da falta. Aplicada ao modelo da LT da Fig. 08. 53

Figura 10-Segunda arquitetura de RNA, com variação de Rf e distância da

falta. Modelo empregado para LT da Fig. 08.

Figura 11-Arquitetura da RNA com dados de treinamento incluindo variação dos quatro parâmetros. Modelo empregado para LT da Fig. 08.

Figura I.1-Diagrama do circuito utilizado para análise pelo programa "TEER".... 88

Figura I.2-Formas de onda das três fases da tensão, formadas a partir de valores fornecidos pelo programa "TEER".

Figura I.3-Formas de onda das três fases da corrente, formadas a partir de valores fornecidos pelo programa "TEER".

Figura II.1-Valores obtidos pelo programa "TEER" e posteriormente filtrados utilizando-se DFT de $1 / 2$ ciclo. 


\section{LISTA DE TABELAS}

Tabela 01-Resultados para a RNA com arquitetura representada pela Fig. 09. ....56

Tabela 02-Resultados da RNA da Fig. 08 para pequenas variações nos dados de treinamento. 57

Tabela 03-Apresentação dos testes da RNA da Fig. 09. 61

Tabela 04-Barramento A com $1.1 \angle 15^{\circ} \mathrm{pu}$, ângulo de incidência da falta de $0^{\circ}$. Utilizada para testar a RNA da Fig. 11 69

Tabela 05 -Barramento A com $1.1 \angle 15^{\circ} \mathrm{pu}$, ângulo de incidência da falta de $30^{\circ}$. Utilizada para testar a RNA da Fig. 11 70

Tabela 06-Barramento A com $1.1 \angle 15^{\circ} \mathrm{pu}$, ângulo de incidência da falta de $45^{\circ}$.

Utilizada para testar a RNA da Fig. 11

Tabela 07-Barramento A com $1.1 \angle 15^{\circ}$ pu, ângulo de incidência da falta de $60^{\circ}$.

Utilizada para testar a RNA da Fig. 11

Tabela 08-Barramento A com $1.1 \angle 15^{\circ} \mathrm{pu}$, ângulo de incidência da falta de $90^{\circ}$.

Utilizada para testar a RNA da Fig. 11

Tabela 09-Barramento A com $1.1 \angle 20^{\circ} \mathrm{pu}$, ângulo de incidência da falta de $0^{\circ}$. Utilizada para testar a RNA da Fig. 11

Tabela 10-Barramento A com $1.1 \angle 20^{\circ} \mathrm{pu}$, ângulo de incidência da falta de $30^{\circ}$. Utilizada para testar a RNA da Fig. 11

Tabela 11-Barramento A com $1.1 \angle 20^{\circ}$ pu, ângulo de incidência da falta de $45^{\circ}$. Utilizada para testar a RNA da Fig. 11 
Tabela 12-Barramento A com $1.1 \angle 20^{\circ} \mathrm{pu}$, ângulo de incidência da falta de $60^{\circ}$.

Utilizada para testar a RNA da Fig. 11

Tabela 13-Barramento A com $1.1 \angle 20^{\circ} \mathrm{pu}$, ângulo de incidência da falta de $90^{\circ}$.

Utilizada para testar a RNA da Figura 11

Tabela 14-Barramento A com $1.1 \angle 20^{\circ} \mathrm{pu}$, ângulo de incidência da falta de $0^{\circ}$.

Variação na capacidade da fonte A. Utilizada para testar a RNA da Fig. 11

Tabela 15-Barramento A com $1.1 \angle 20^{\circ} \mathrm{pu}$, ângulo de incidência da falta de $0^{\circ}$.

Modificações nos parâmetros $Z_{a} / Z_{b}$. Utilizada para testar a RNA da Fig. 11 80 


\section{LISTA DE ABREVIATURAS E SIGLAS}

A/D - analógico/digital

ABNT - Associação Brasileira de Normas Técnicas

CA - corrente alternada

CC - corrente contínua

D/A - digital/analógico

DFT - "Discrete Fourier Transform" (Transformada Discreta de Fourier)

EAT - Extra Alta Tensão

EMTP - Eletromagnetic Transients Program

FFT - "Fast Fourier Transform" (Transformada Rápida de Fourier)

LT - Linha de Transmissão

pu - por unidade

Rf - resistência de falta

rms - "root mean square" (valor médio quadrático)

RNA - Rede Neural Artificial

s.c.a. - "steel core aluminium" (cabo de aço com alma de alumínio)

SEP - Sistema Elétrico de Potência

TC - transformador de corrente

TP - transformador de potencial 


\section{LISTA DE SÍMBOLOS}

$\xi_{\mathrm{i}} \quad$-valor numérico da entrada $\mathrm{i}$, na primeira camada de neurônios, da Rede Neural Artificial.

b,B -valor numérico de ajuste aplicado a função de transferência da Rede Neural Artificial, "bias".

$\mathrm{I}_{\mathrm{i}} \quad$-corrente no barramento i.

$\mathrm{O}_{\mathrm{i}} \quad$-saída numérica do neurônio i de uma Rede Neural Artificial.

S -saída numérica da Rede Neural Artificial, valores entre [0,1].

$\mathrm{V}_{\mathrm{i}} \quad$-tensão no barramento $\mathrm{i}$.

wij,Wij-valor numérico do "peso" da conexão entre os neurônios i e j.

$Z_{0} \quad$-impedância de seqüência zero.

$Z_{1} \quad$-impedância de seqüência positiva.

$Z_{i} \quad$-impedância do barramento i, indicada em $\Omega$. 


\section{RESUMO}

Jorge, David C. - Redes Neurais Artificiais Aplicadas a Proteção de Sistemas Elétricos de Potência - São Carlos 1997, 96p. - Dissertação (Mestrado) - Escola de Engenharia de São Carlos, Universidade de São Paulo.

Um relé de distância utilizado na proteção de Linhas de Transmissão é usualmente projetado para atuar sob condições fixas de operação. Portanto, o desempenho destes relés é afetado pela mudança no ponto de operação do sistema. Grandes avanços, relativos à proteção, podem ser alcançados com a implementação de reconhecimento de padrões para o diagnóstico de faltas em sistemas elétricos de potência. Este trabalho demonstra a utilização de Redes Neurais Artificiais operando como um classificador de padrões para a operação de um relé de distância. $\mathrm{O}$ projeto utiliza a magnitude dos fasores das três fases de corrente e tensão, de um dos barramentos da Linha de Transmissão, como dados de entrada. O uso de Redes Neurais Artificiais resulta em um melhor desempenho do relé, mantendo seu alcance mesmo diante de diferentes condições de falta ou mudanças no ponto de operação do sistema.

Palavras Chave: sistemas de potência, relés de distância, proteção de sistemas elétricos de potência, Redes Neurais Artificiais. 


\begin{abstract}
Jorge, David C. - Artificial Neural Networks Applied to the Protection of Electrical Power Systems - São Carlos 1997, 96p. - Dissertação (Mestrado) - Escola de Engenharia de São Carlos, Universidade de São Paulo.
\end{abstract}

A distance relay for the protection of transmission lines is usually designed on the basis of fixed settings. The performance of such relays is therefore affected by the changing network parameters. The implementation of a pattern recognizer for power system diagnosis can provide great advances in the protection field. This work demonstrates the use of an Artificial Neural Network as a pattern classifier for a distance relay operation. The scheme utilizes the magnitudes of three phase voltage and current phasors, from one busbar of the transmission line, as inputs. An improved performance with the use of an Artificial Neural Networks approach is experienced once the relay can operate correctly, keeping the reach when faced with different fault conditions as well as network parameters change.

Keywords: power systems, distance relays, power system protection, Artificial Neural Networks. 


\section{1-INTRODUÇÃO}

\section{1-Faltas em Sistemas Elétricos de Potência}

O fornecimento de energia elétrica deve ser realizado de forma a otimizar sua utilização e garantir sua continuidade. Para que estes objetivos possam ser desempenhados com eficiência, a elaboração de um projeto do Sistema Elétrico de Potência (SEP) se faz necessária. Diversas considerações são tomadas durante o desenvolvimento destes projetos, tais como [1]:

- $\quad$ a elaboração de programas ótimos de geração;

- a constituição de esquemas de interconexão apropriados (ligações da malha de transmissão de energia do SEP);

- $\quad$ a utilização de um conjunto de proteções adequado.

Faltas em um SEP, na maioria dos casos descritas como um curto, ocorrem de forma aleatória. Um sistema de proteção deve resguardar o SEP dos efeitos danosos de uma falta com duração prolongada. Se o componente faltoso (Linha de Transmissão (LT), barramento, transformador, etc.) não for isolado rapidamente do sistema, este poderá conduzir o SEP para sua instabilidade ou para a atuação automática dos demais sistemas de proteção (situação conhecida como "efeito cascata"). A persistência da falta 
pode ainda causar danos a equipamentos próximos ao elemento faltoso, devido aos elevados valores de correntes, as correntes desequilibradas ou ainda baixas tensões produzidas pela falta [2].

\section{2-Relés}

Os estudos desenvolvidos neste trabalho abrangem proteção através de relés. Segundo a ABNT: "o relé é um dispositivo por meio do qual um equipamento elétrico é operado quando se produzem variações nas condições deste equipamento ou do circuito em que ele está ligado, ou em outro equipamento ou circuito associado" [1]. Geralmente os valores apresentados a um relé são tensão e corrente, e a saída é um sinal entre os contatos do relé (ligado/desligado) [2].

Apesar de um sistema de proteção ser usualmente compreendido como um relé, este consiste de vários outros subsistemas que contribuem para o processo de remoção da falta. Estes subsistemas se encontram representados na Fig. 01.

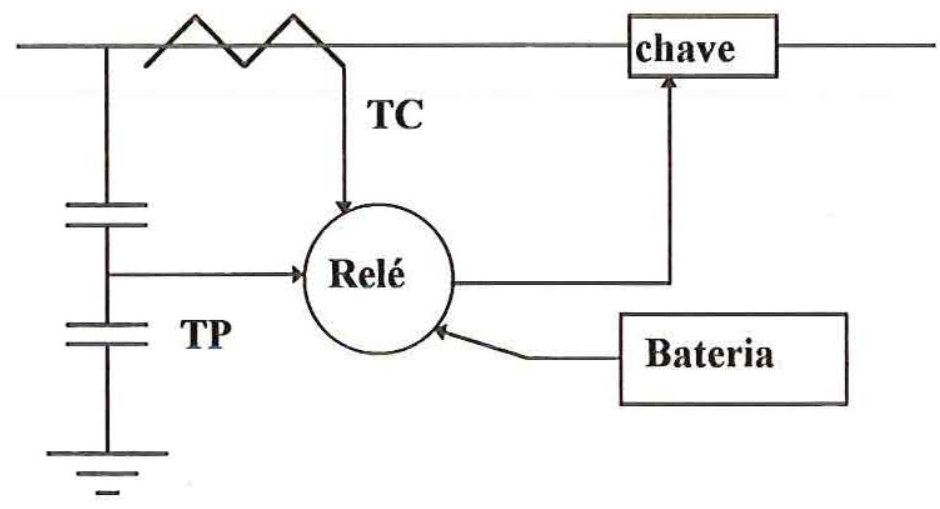

Figura 01-Representação simples de um relé. 
Observa-se na figura a presença de transdutores. Estes são representados pelos transformadores de corrente (TC) e de potencial (TP), que são necessários para que os valores de alta magnitude de corrente e tensão do sistema de potência tenham seus níveis reduzidos; assim a manipulação de energia será menor para os demais componentes do sistema. Observa-se ainda que o relé e a chave de abertura possuem alimentação através de uma bateria, evitando sua dependência do fornecimento de energia do SEP a ser monitorado. A chave de abertura, presente na representação é a responsável pelo isolamento do circuito faltoso, interrompendo a ligação quando a corrente estiver próxima de zero [2].

O relé é o dispositivo que responde as condições de suas entradas, de maneira a prover sinais de saída apropriados para o sistema de proteção, indicando quando as condições de entrada correspondem a faltas. Os relés são os elementos responsáveis pelas análises lógicas no sistema de proteção. $\mathrm{O}$ projeto de um relé deve ser tal que apenas as condições de falta, para as quais ele é responsável, resultem em um sinal de atuação para a proteção, e nenhuma outra condição diferente destas deve resultar na atuação do relé.

Os relés utilizados em SEPs podem ser classificados como [2]:

- Relés de Magnitude: Estes relés respondem a magnitude dos sinais de entrada. Um exemplo típico é o relé de sobrecorrente que responde às mudanças na magnitude do sinal de corrente fornecido como entrada.

- Relés Direcionais: Estes relés respondem ao ângulo de fase entre dois sinais de entrada em CA. Um relé direcional convencionalmente compara o ângulo de fase de uma 
corrente com relação a tensão. Pode-se comparar também o ângulo de fase entre dois sinais de corrente.

- Relés de Distância: Estes relés respondem a razão entre dois sinais de entrada expressos em fasores, normalmente a corrente e a tensão. A razão entre estes dois fasores é um número complexo, e o relé de distância deverá responder a magnitude deste número em relação a uma característica de operação.

- Relés Diferenciais: Estes relés respondem a magnitude resultante da soma algébrica de duas ou mais entradas. Na sua forma mais comum, estes relés respondem a soma algébrica de sinais de corrente incidentes em uma zona de proteção. Caso não haja uma falha interna, esta soma algébrica deve ser próxima de zero.

- Relés com fio piloto: Estes relés utilizam informação de locais remotos como sinal de entrada. Este tipo de proteção geralmente comunica a decisão feita por um relé local de um dos quatro tipos descritos anteriormente para relés em terminais remotos de uma LT.

\section{3-Relés Digitais}

Com o surgimento dos computadores digitais no início da década de 60 começaram a existir várias soluções computacionais para os diversos problemas, em todas as áreas de conhecimento. Na Engenharia Elétrica este foi um período durante o qual os computadores digitais, lenta e sistematicamente, foram substituindo muitas das 
ferramentas de análise de circuitos na área de potência. Inicialmente os problemas de fluxo de carga, estabilidade, curto-circuito, cuja solução são as primeiras preocupações dos planejadores de SEP's; foram convertidos em programas computacionais. Os relés foram visualizados como os próximos dispositivos a serem computadorizados, porém nesta época não havia capacidade técnica dos dispositivos computacionais para possibilitar o desempenho de alta velocidade necessárias aos relés. Também não ocorriam incentivos econômicos para estes estudos. A evolução dos computadores nos anos posteriores foi tão rápida que os algoritmos sofisticados, demandados pelos programas de proteção utilizados nos relés, finalmente encontraram uma correspondência em velocidade e economia nos modernos microcomputadores, tornando possível a "digitalização" dos relés [2].

Entre os beneficios advindos dos relés digitais podemos citar [2]:

- Custo: Com características equivalentes aos relés convencionais, o custo do relé digital é a principal consideração para sua aceitação. Nos primeiros estágios dos relés digitais seu custo era entre 10 a 20 vezes maior que o custo de um relé convencional. Nos anos seguintes o custo do relé digital foi reduzindo, ao mesmo tempo que seu poder computacional aumentou substancialmente. $\mathrm{O}$ custo dos relés convencionais aumentou ao longo deste mesmo período, devido inicialmente às modificações em seus projetos para melhorar seu desempenho, mas também por causa da inflação geral e o volume relativamente pequeno de produção e vendas. É estimado que para um mesmo desempenho, o custo de um relé digital sofisticado (incluindo o preço do programa computacional) atualmente deva ser o mesmo que o de um relé convencional. 
- Possibilidade de auto-checagem: O relé digital pode ser programado para monitorar de forma constante o funcionamento de seu "hardware" e seu programa computacional, detectando então qualquer defeito que possa ocorrer. Pode ser programado também para desligar-se do serviço, sem interromper o SEP, se algum defeito for encontrado em seu funcionamento, e enviar uma informação de seu estado ao centro de operações.

- Integração digital no SEP: Microcomputadores e tecnologia digital estão se tornando a base da maioria dos sistemas em subestações. Medições, comunicações, telemetria e controle estão sendo digitalizados em todos os SEP's. Os relés digitais irão aumentar o desempenho e facilitar o monitoramento, além de apresentarem maior interação, neste novo sistema.

- $\quad$ Flexibilidade quanto a função: Um computador digital pode ser programado para executar diferentes trabalhos ou várias funções. Em um relé a relação entre os sinais de entrada e a saída dependem destas funções. No entanto, devido a sua natureza computacional o mesmo pode ser programado para realizar funções diferenciadas.

A Fig. 02 apresenta um esquema de "hardware" de um relé digital, onde pode-se observar a seguinte seqüência:

(1) Os sinais de corrente e tensão são fornecidos através de transdutores para sua atenuação inicial. 
(2) Os sinais de corrente e tensão entram em um módulo de "interface" onde serão novamente atenuados, para finalmente atingirem níveis adequados para digitalização. Usualmente a entrada de conversores analógico/digital (A/D) é restrito a $\pm 10 \mathrm{~V}$. Assim, a escala do secundário dos transformadores deste módulo deverá portanto ser condicionada para estes valores. Há necessidade de divisores resistivos ou mesmo a presença de transformadores de corrente auxiliares para se obter este nível do sinal. Isto é justificado pois a saída convencional do secundário de transformadores de potencial é de $67 \mathrm{~V}$ rms para uma conexão fase-neutro. $\mathrm{O}$ sinal de corrente deverá ser transformado em um sinal de tensão, haja visto que os equipamentos digitais operam apenas com sinal de tensão. O módulo de "interface" também é composta de filtros analógicos passa-baixa (passivos ou ativos), visando eliminar o fenômeno denominado sobreposição de espectros ("aliasing"). O problema advindo da sobreposição de espectros também é uma fonte de erros da conversão A/D [2].

(3) O módulo de sincronização dos sinais é composto por um ou mais multiplexadores e "sample and hold", dependendo da arquitetura adotada para o relé. Os instantes de amostragem são determinados por um "clock", que devem produzir pulsos em uma taxa fixa. Para cada instante, definido pelo "clock", ocorre uma conversão dos valores instantâneos dos sinais analógicos de entrada em uma forma digital. Como o relé em geral, requer várias entradas, várias conversões são realizadas. O multiplexador faz com que os sinais utilizados na conversão sejam processados por um único conversor $\mathrm{A} / \mathrm{D}$.

(4) $\mathrm{O}$ sinal digital segue para o dispositivo processador, para análise e aplicação da rotina computacional nele contido, operando conforme a finalidade para a qual o relé foi 
projetado. A atuação ou não da proteção é sinalizada na forma digital, fornecida a um controle que irá atuar, se necessário, na chave do circuito, isolando o setor defeituoso [2].

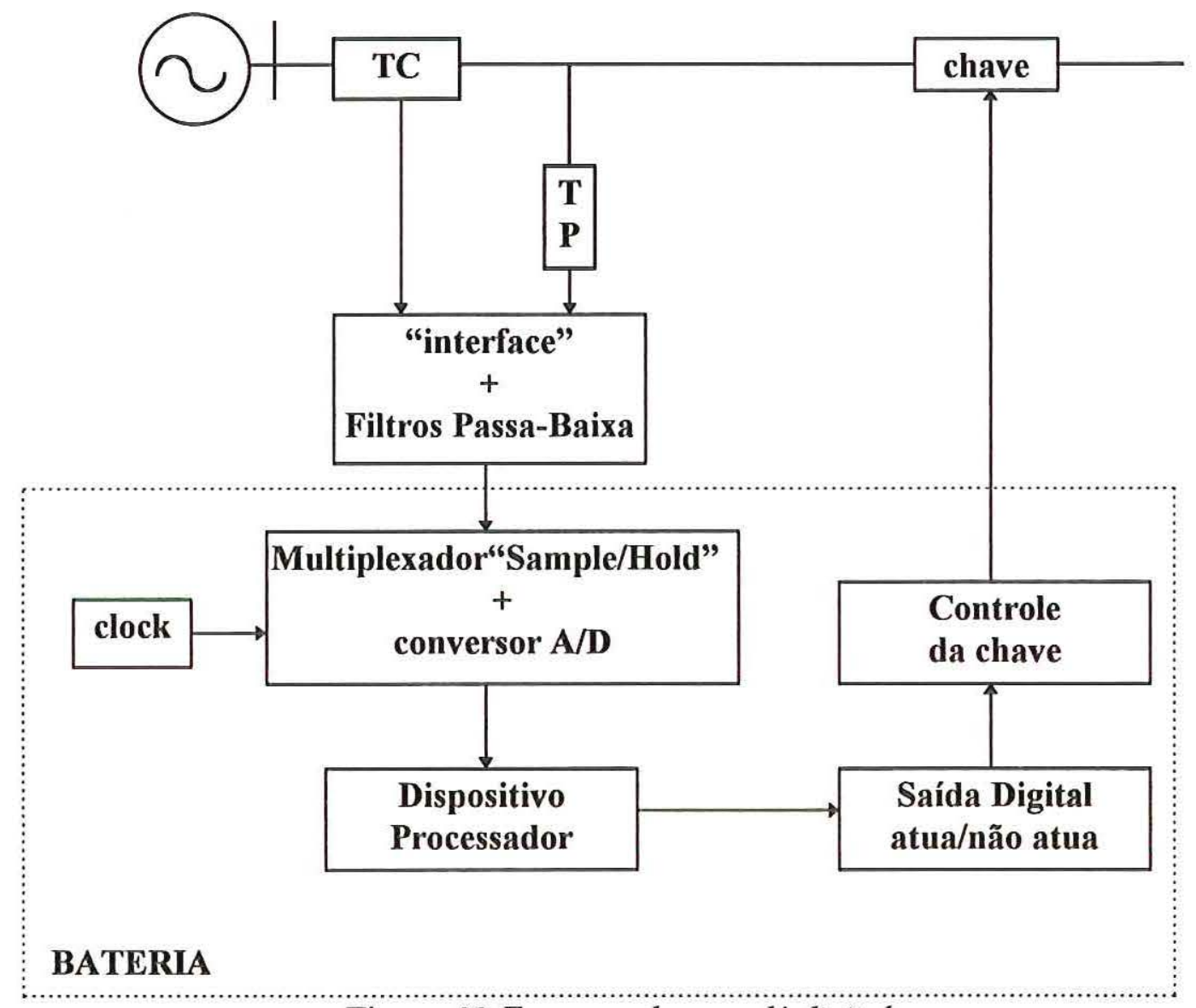

Figura 02-Esquema de um relé digital

\section{4-Relés Digitais de Distância}

Entre as diversas faltas detectadas em SEPs, uma que merece destaque é a relacionada a problemas com a LT. O contato entre condutores, ou de um condutor e a terra é responsável por faltas em linhas, devendo esta situação ser detectada e sanada da forma mais rápida e precisa possível. Com relação a faltas ocorridas nas LT's, as do tipo 
fase-terra são as mais comuns e em algumas linhas responsáveis por mais de $80 \%$ das ocorrências [1].

O relé, que realizaria a proteção mais correta de um sistema, deve detectar a relação entre a corrente em um extremo da linha e compará-la com a corrente que está no outro extremo. Porém este tipo de proteção seria extremamente complexo e dispendioso [1]. A utilização do valor de corrente em uma lado da LT para indicar tal situação também se mostra falho, pois o valor de pico de corrente ajustado para atuação de um relé de sobrecorrente deverá estar entre a corrente com o máximo valor de carga e o mínimo valor de corrente de falta para a qual o relé estará exposto. Em redes de altatensão e extra-alta-tensão estes parâmetros geralmente não estão muito bem definidos, nem mesmo estão distantes o suficiente um do outro para que seja possível uma seleção segura do ajuste de atuação do relé. Para estas situações, portanto, o princípio de proteção utilizado nos relés deverá ser outro. Os relés conhecidos por relés de distância oferecem excelentes resultados para a proteção sob todas as circunstâncias descritas acima [2].

A forma de operação do relé de distância pode ser melhor analisada considerando a LT mostrada na Fig. 03, supondo uma falta a uma distância fracionária (K) do relé localizado no barramento A. Se há uma falta fase-fase entre as fases $\mathrm{x}$ e y com $\mathrm{x} \neq \mathrm{y}$; e $\mathrm{x}, \mathrm{y}=\mathrm{a}, \mathrm{b}, \mathrm{c}$; pode ser mostrado que [2]:

$$
\frac{E_{x}-E_{y}}{I_{x}-I_{y}}=k Z_{1}
$$

onde $Z_{1}$ é a impedância de seqüência positiva de toda a LT. Similarmente, para uma falta fase-terra, na fase $x$, então: 


$$
\frac{E_{x}}{I_{x}-m I_{0}}=k Z_{1}
$$

sendo $m$ igual a $\left(Z_{0}-Z_{1}\right) / Z_{1}$, e $Z_{0}$ é a impedância de seqüência zero da LT. A razão das tensões e correntes apropriadas representa a fração da impedância de linha (seqüência positiva) na qual a falta ocorre. A razão computada pode ser comparada com a impedância total de seqüência positiva da zona protegida, e se for menor a atuação da proteção é realizada.

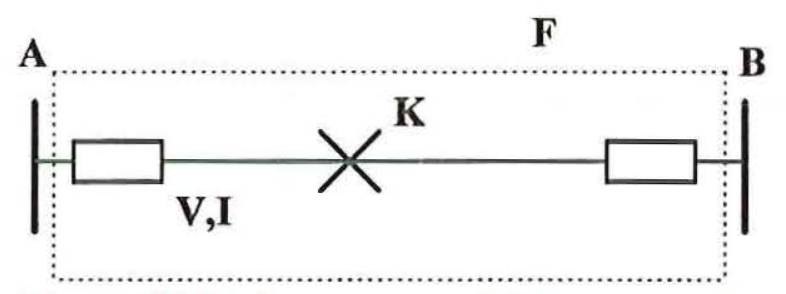

Figura 03-Linha com uma falta na zona de proteção [2].

Deve ser notado que a razão de dois fasores complexos expressos em (1) e (2) é também um número complexo. Por conseguinte, a comparação que representa a condição de operação é feita em um plano complexo R-X. Um retângulo, círculo ou segmento de um círculo envolvendo a linha são formas aceitáveis e definem as zonas de proteção no plano R-X [2].

A operação de um relé de distância pode ser caracterizada pelos passos descritos a seguir [1]:

(1) Obtenção dos sinais de corrente e tensão da LT.

(2) Obtenção da razão entre os fasores de tensão e corrente, conhecido como cálculo da impedância (utilizando-se (1) ou (2), dependendo do tipo de falta). 
(3) Determinação se o valor de impedância calculada se encontra interna ou externamente a zona de proteção do relé, através de sua característica de operação. Se o relé for temporizado, aguardar até que se exceda o tempo determinado para a atuação da proteção. Realizar então a ação da proteção, com o comando de abertura da chave, se necessário.

A grande limitação da proteção digital a distância é que ela é usualmente projetada com características fixas de operação. Assim, o alcance da zona primária de tais relés pode ser afetada pelas diferentes condições de operação da rede em consideração. Com a finalidade de minimizar o efeito de tal situação para as características convencionais, uma margem de segurança é necessária para evitar a variação na "zona de proteção".

Este trabalho mostra a aplicação de Redes Neurais Artificiais (RNA's) para proteção a distância de LT's. RNA's são uma tentativa de reproduzir os processos de aprendizado do cérebro humano. Seu potencial tem levado pesquisadores da área de Sistemas Elétricos a considerá-lo para aplicações tais como previsão de carga, despacho econômico e proteção.

A aplicação em questão simula um relé de distância baseado em RNA o qual pode reconhecer as condições mutantes do sistema e manter a sua regulação, melhorando assim o desempenho dos mesmos se comparados a relés digitais convencionais.

No capítulo 2 é apresentado um breve levantamento bibliográfico das aplicações de RNA's em Sistemas Elétricos de Potência (SEP). No Capítulo 3 é apresentado um resumo teórico sobre RNA's e a aplicação considerada neste trabalho. No Capítulo 4 são fornecidos os resultados obtidos com a aplicação de RNA's atuando como relés de 
distância. O Capítulo 5 refere-se às conclusões obtidas com o desenvolvimento deste trabalho. 


\section{2-LEVANTAMENTO BIBLIOGRÁFICO}

Existe uma grande quantidade de publicações envolvendo o estudo de Inteligência Artificial e suas sub-áreas. As Redes Neurais Artificiais se enquadram em uma das sub-áreas da Inteligência Artificial de maior destaque na atualidade. Parte das publicações a respeito de Redes Neurais Artificiais envolvem estudos correlatos a engenharia elétrica de potência. Este capítulo apresenta inicialmente um breve levantamento no que diz respeito ao uso de Inteligência Artificial em subestações de potência. Em seguida é apresentado um levantamento mais detalhado da aplicação específica das RNA's na proteção de sistemas e assuntos correlatos.

Alguns trabalhos utilizando Inteligência Artificial, e sua aplicação em SEP, merecem ser destacados. Um dos primeiros trabalhos desenvolvidos é o de Sakaguchi, $\mathrm{T}$.; et al. [3], onde é descrita uma rotina computacional baseada em sistemas inteligentes para se obter a seqüência de religação de uma seção elétrica, após a ocorrência de uma falta.

Outra publicação a ser destacada é a de Talukdar, S.N.; et al. [4], que descreve a criação de dois programas de computador utilizando Inteligência Artificial para uma aplicação prática. O primeiro programa simula o comportamento do sistema de proteção em redes elétricas de potência e o segundo é um sistema inteligente para diagnóstico de faltas. 
Uma das utilidades que pode ser destacada na utilização de Inteligência Artificial é a predição de pontos de instabilidade do sistema. Entre as pesquisas que desenvolvem este processo, a realizada por Kukui, C. e Kawakami, J. [5] pode ser citada, a qual utiliza a tecnologia de Inteligência Artificial para desenvolver uma rotina de estimação de sistemas faltosos. O estudo utiliza informações do estado dos relés de proteção e das chaves presentes no circuito.

A possibilidade de diagnosticar a eficiência do sistema de proteção de uma subestação, utilizando Inteligência Artificial, foi estudada em uma publicação de Kezunovic, M; ; et al. [6]. Utilizando sistemas inteligentes, a proposta desta pesquisa é a utilização de dados de uma subestação, armazenados anteriormente, para análise das causas das perturbações e o desempenho das operações de proteção.

Com o grande aumento de pesquisas relacionadas a Redes Neurais Artificiais, surge a necessidade de conhecer algumas aplicações deste novo tipo de recurso na engenharia elétrica. Entre diversas publicações segue-se um capítulo de Sharkawi, M. A.; et al. [7] que pode ser considerado como uma análise generalizada das possibilidades de implementação de Redes Neurais Artificiais em Engenharia Elétrica de Potência. Este trabalho apresenta uma breve introdução teórica a respeito do assunto, seguido de aplicações de Redes Neurais Artificiais. Neste trabalho são citados diversos problemas comuns aos Sistemas Elétricos de Potência, entre eles: estabilidade, modelamento de máquinas síncronas, identificação e estimação de harmônicos na rede, etc., e a aplicação de Redes Neurais Artificiais para a solução dos mesmos.

Ainda com respeito às publicações do uso de Redes Neurais Artificiais, envolvendo o problema de análise e estudos da localização de faltas em Linhas de Transmissão de alta potência, é importante citar a publicação de Kanoh, H.; et al. [8]. Nesta publicação um modelo de localizador de faltas é proposto, utilizando 
reconhecimento de padrões, baseado no processo de inferência. Faz-se uso de Redes Neurais Artificiais de três camadas e o método de convergência utilizado é o "backpropagation". Os dados envolvidos são as correntes de falta. Utiliza-se a diferença entre seus ângulos de fase e seus módulos. Os dados da diferença entre os ângulos de fase da corrente são fornecidos a uma Rede Neural isolada, para análise, enquanto os dados dos módulos das correntes são fornecidos a uma outra Rede Neural. Estas Redes Neurais fornecem uma saída cada uma. O objetivo é encontrar os possíveis candidatos a seção onde se encontra a falta. As saídas das duas primeiras Redes Neurais são utilizadas como entradas para uma terceira Rede Neural. A terceira Rede Neural também utiliza, junto com as saídas das outras duas Redes Neurais, os módulos das correntes como entrada, e fornece como resultado a provável localização da falta. Os resultados obtidos apresentados pela publicação podem ser considerados bastante satisfatórios. Conforme citado na publicação, mesmo na análise de um sistema elétrico complexo, as respostas se dão de forma satisfatória. Os diagramas das Redes Neurais Artificiais são obtidos de forma totalmente empírica. Pode-se questionar, no entanto, a necessidade de utilizar uma quantidade tão elevada de Redes Neurais para a resolução deste problema.

Uma pesquisa também a ser destacada com respeito à proteção de sistemas elétricos de potência utilizando RNA's são duas publicações de Chakravarthy, S.K.; et al. [9] [10]. Esta pesquisa utiliza reconhecimento de padrões, para a localização de faltas em uma Linha de Transmissão utilizando Redes Neurais Artificiais. Estas publicações desenvolvem um estudo teórico inicial das limitações do sistema de proteção atual. Posteriormente oferecem uma solução para o problema baseada no reconhecimento de padrões. Os resultados obtidos demonstram que a utilização de reconhecimento de padrões para otimizar a proteção de um sistema elétrico de potência é viável. 
A utilização de Redes Neurais Artificiais pode também ocorrer em aplicações em tempo real. A publicação de Swarup, K.S. e Chandrasekharaiah, H.S. [11] descreve a utilização de Redes Neurais Artificiais para a deteç̧ão e o diagnóstico de falta no sistema elétrico, em tempo real. Esta publicação apresenta os diferentes resultados obtidos para diferentes casos de faltas, utilizando uma representação de Redes Neurais Artificiais com apenas uma camada oculta. Uma parte importante apresentada por este trabalho é quanto a estudos realizados com modificações da estrutura da Rede Neural Artificial. Ocorrem variações da quantidade de camadas ocultas utilizadas na representação da Rede Neural Artificial, acompanhadas dos diferentes desempenhos obtidos. Conforme ocorre a variação de camadas ocultas, obtém-se diferentes desempenhos da Rede Neural Artificial utilzada.

Outra publicação relevante foi realizada por Cen, W.; et al. [12], tratando de um novo algoritmo de Redes Neurais Artificiais baseado na realimentação da informação. Fazendo uso de informações peculiares do sistema, tais como posição das chaves e estado dos relés de um sistema elétrico, o autor argumenta que se poderia identificar rapidamente setores defeituosos do circuito, mesmo com informações incompletas. É desenvolvida uma rotina, com funções similares ao "Back-Propagation", apresentada como uma rotina mais eficiente de convergência. Porém não é fornecida de forma clara a rotina utilizada. Somente são citados uma seqüência simplificada do algoritmo e alguns exemplos práticos. A publicação também informa que a proposta deste algoritmo ainda se encontra em estudos.

Outra publicação de destaque com respeito à utilização de memórias associativas é a realizada por Silva, A. P. A.; et al. [13]. A utilização de memórias associativas para auxiliar na reconfiguração de um sistema elétrico é a proposta elaborada por este trabalho. Faz-se uso de Redes Neurais Artificiais, armazenando-se um conjunto de 
possíveis configurações do sistema elétrico. Posteriormente, as memórias são utilizadas em tempo real para localizar a falta, a partir do estado dos equipamentos do sistema de proteção, mesmo com a incorreta operação de alguns equipamentos. A proposta é realizada baseada em uma subestação de $500 \mathrm{kV}$, porém pode ser estendida para diferentes modelos de subestações. Mesmo não se tendo obtido excelentes resultados neste trabalho, é possível notar que a utilização de Redes Neurais Artificiais, como ferramenta auxiliar, deva ser alvo de mais estudos.

Um outro trabalho que merece destaque é o desenvolvido por Khaparde, S.A; et al. [14]. Esta publicação propõe um modelo particularmente mais simples de Rede Neural Artificial, para proteção a distância de LT's. Utilizando-se de dados de fácil aquisição (corrente e tensão) é desenvolvido um modelamento simples de representação destes dados. $\mathrm{O}$ trabalho se baseia em uma construção matricial dos dados, de corrente e tensão, para representar as condições em que se encontra o sistema. Desta forma o reconhecimento de padrões torna-se mais simples de ser visualizado. Uma Tabela de relações entre tensão e corrente como dados de entrada é utilizada em uma Rede Neural Artificial tipo "Adaline” (Adaptive Linear), cuja entrada e saída de informação se dão na forma binária. Apesar de ser um modelo simples de ser reproduzido experimentalmente, pode ser considerado como uma primeira forma de pesquisa do desempenho de Redes Neurais Artificiais aplicadas a este fim.

Cabe ainda citar dois trabalhos desenvolvidos por Aggarwal, R.; et al.[15] e [16]. Estes estudos incluem a utilização de Redes Neurais Artificiais para determinar se uma falta que esta ocorrendo no sistema é temporária ou permanente, para finalidade de religamento automático. Os trabalhos obtêm uma seqüência de resultados satisfatórios com um alto desempenho das Redes Neurais Artificiais utilizadas. Os estudos realizados 
destacam que o desempenho de Redes Neurais Artificiais mediante a entrada de sinais ruidosos mantém-se satisfatório.

Cabe ainda citar a técnica registrada no trabalho de Dalstein,T.; et al. [17]. Este trabalho realiza estudos da aplicação de Redes Neurais Artificiais operando como um classificador de faltas em uma Linha de Transmissão. Este estudo utiliza alguns tipos de faltas em uma Linha de Transmissão como: fase-terra, fase-fase-terra e trifásica. Foram desenvolvidas várias simulações para serem utilizadas no treinamento e teste da Rede Neural Artificial. Os resultados obtidos com as diferentes situações testadas, após a aplicação das técnicas de Redes Neurais Artificiais, foram excelentes. Este trabalho demonstra a possibilidade de utilizar Redes Neurais Artificiais operando como classificadores de faltas, demonstrando que a utilização desta técnica visando ampliar o atual desempenho dos sistemas de proteção é uma realidade.

Existem ainda publicações recentes envolvendo a aplicação de Redes Neurais Artificiais operando especificamente como relés de proteção. Estes estudos, mostram resultados satisfatórios na utilização de Redes Neurais Artificiais, visando aumentar a eficiência dos dispositivos de proteção em uma Linha de Transmissão. A publicação de Sidhu, T.S.; et al. [18] é o exemplo mais claro destes estudos. O estudo almeja aumentar a eficiência dos relés direcionais, responsáveis pela determinação da direção da corrente de falta em um sistema elétrico, e otimizar sua velocidade de atuação. $\mathrm{O}$ trabalho apresenta os resultados de um discriminador de faltas baseado em Redes Neurais Artificiais. O modo como são realizados os estudos, assim como os excelentes resultados obtidos, indicam a utilização da técnica de Redes Neurais Artificiais para a proteção do Sistema Elétrico de Potência como uma nova ferramenta de grande valia.

O trabalho mais recente de Dalstein, T.; et al. [19] contém idéias próximas ao objetivo desta tese aqui apresentada. O trabalho visa estudar a aplicação de Redes 
Neurais Artificiais como ferramenta para estimar a área de proteção em relés de distância de alta velocidade. Neste trabalho as Redes Neurais Artificiais são utilizadas para a seleção da área a ser desligada em um Sistema de Elétrico de Potência. São considerados vários itens nos estudos tais como: atuação da "proteção de retaguarda", onde é aguardado um tempo para a correta atuação de um relé, caso isto não ocorra outro relé atua isolando a área com problemas; estudos de operação da proteção sob diversos tipos de falta; presença de arcos elétricos nas faltas; entre outros. A Rede Neural Artificial utilizada possui como entrada de dados os valores de tensão e corrente de forma discretizada, estes valores são fornecidos à rede onde é determinado a área a ser "desligada". O método de "back-propagation" é utilizado para solucionar as Redes Neurais Artificiais propostas. Os resultados obtidos neste trabalho são muito encorajadores, apontando a possibilidade da utilização de Redes Neurais Artificiais aplicadas a proteção de Sistemas Elétricos de Potência. 


\section{3-REDES NEURAIS ARTIFICIAIS E SUA APLICAÇÃO NA PROTEÇÃO DE SISTEMAS ELÉTRICOS DE POTÊNCIA}

\section{1-Conceitos Biológicos Básicos do Neurônio}

O cérebro humano pode ser considerado o mais intrínseco dos computadores presentes no mundo. Existem diversas razões para se desejar que computadores operem como o cérebro humano, entre elas [16]:

- A forma robusta como o cérebro opera; por exemplo células cerebrais morrem a todo o instante, porém o seu desempenho geral mantém-se inalterado.

- O cérebro opera com instruções extremamente complexas e incompletas.

- $\quad$ Possui um elevado paralelismo em seu processamento.

- Tratamento especial para situações difusas, como exemplo a possibilidade de recorrer a um "banco de dados" para tentar analisar uma situação inusitada.

- $\quad$ É pequeno, compacto e despende pouca energia para seu processamento.

A base do processamento realizado no cérebro humano segue as conexões existentes entre as estimadas $10^{11}$ células neurais, conhecidas por neurônios, presentes em sua composição. 
O cérebro humano possui um processamento com elevado paralelismo. Os neurônios operam em paralelo, e encontram-se conectados por uma extensa malha de comunicação com ramificações. Estas ramificações de comunicação são realizadas por uma conexão principal longa, conhecida por axônio, cuja conexão terminal é feita através de uma conexão especial, a sináptica, e diversas ramificações curtas, os dendritos. As conexões sinápticas geralmente ocorrem entre axônios e dendritos, e possuem um retardo na transferência do sinal da ordem de milésimos de segundos. A forma de comunicação entre os neurônios pode ser descrita como uma troca de impulsos elétricos. A existência da natureza elétrica entre neurônios foi constatada pela primeira vez por Galvani (1780). Estes impulsos são resultantes de um equilíbrio químico envolvendo a presença dos elementos sódio e potássio, conhecido como "bomba de sódio". O impulso nervoso é uma "onda" contínua que se propaga através da polarização e despolarização das membranas do axônio em toda sua extensão. Após o envio do sinal elétrico na conexão existe um tempo de refração, para que um próximo sinal possa ser enviado [20]. A forma fisiológica de um neurônio é mostrada na Fig. 04.

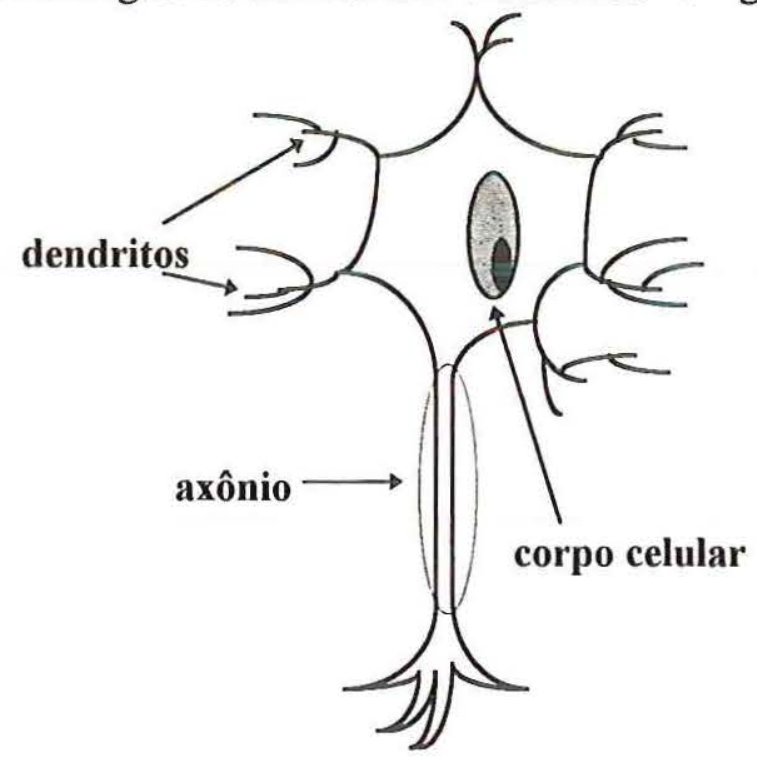

Figura 04-Diagrama esquemático de um neurônio humano. 


\section{2-As Vantagens da Implementação de uma Rede Neural Artificial}

A idéia básica para a constituição de uma RNA envolve a possibilidade de "tomada de decisão" de um problema em estudo. A possibilidade de oferecimento de uma resposta a uma situação totalmente desconhecida e inesperada é a grande vantagem da utilização de Redes Neurais Artificiais.

O que deve garantir a obtenção de uma melhor resposta desejada é, além de uma arquitetura adequada, o treinamento da Rede Neural Artificial de forma eficiente. O treinamento da Rede Neural Artificial desenvolvida definirá a qualidade de suas respostas para as diferentes entradas as quais elas será submetida.

Pode-se “ensinar" a Rede Neural Artificial de duas maneiras básicas [22]:

- $\quad$ Treinamento supervisionado, aqui o aprendizado é realizado na base de uma comparação direta entre a saída fornecida pela RNA e a resposta correta, conhecida.

- Treinamento não supervisionado, onde as informações fornecidas para a rede não possuem uma resposta conhecida. A única informação é a relação entre os dados de entrada ou sinais de entrada. A rede deve criar a partir destas relações suas saídas, conforme os sinais de entrada.

Cabe salientar que não apenas a forma como a RNA é treinada influi em seu desempenho, mas também a quantidade de casos utilizados em seu treinamento e a ordem com a qual estes casos são introduzidos para o treinamento da rede em questão. 
Com as ferramentas matemáticas disponíveis podem-se elaborar diversos algoritmos de RNA's. Também é possível descrever as principais vantagens destes algoritmos com relação aos algoritmos convencionais de programação:

- $\quad$ Rápidas decisões em tempo real, para alguns problemas de amplo espectro.

- $\quad$ Pode prover soluções para problemas com situações inusitadas.

- $\quad$ Pode operar com problemas em parte da rede.

- Pode ser treinada "off-line".

A utilização de RNA's tem crescido muito nos recentes trabalhos de pesquisa, em diversos campos. Pode-se concluir que as grandes vantagens apresentadas por sua teorias; principalmente a possibilidade de obtenção de respostas independente da quantidade de dados, tem refletido positivamente nos meios científicos. Existem porém algumas desvantagens apresentadas pela utilização de Redes Neurais Artificiais, entre elas [21]:

- A determinação da forma de treinamento deve ser muito bem estudada. A rede pode necessitar de novos treinamentos, a medida que ocorre variação significativa no comportamento dos dados de entrada.

- Não há uma maneira de garantir a máxima otimização na resposta.

- Não há garantias de se encontrar a melhor arquitetura possível. 
- Há dificuldade em definir os parâmetros da RNA, tais como: taxa de aprendizagem, função de transferência, entre outros.

- A solução depende da forma como foi aplicado o treinamento à rede em questão.

- $\quad$ O processamento de uma rede neural biológica é paralelo. Em Redes Neurais Artificiais a maioria das simulações e processamentos envolvendo a utilização de microcomputadores deve-se limitar ao processamento serial presente nestes equipamentos no presente momento.

Apesar destes problemas as grandes vantagens citadas anteriormente resultam no grande atrativo que existe nas pesquisas de Redes Neurais Artificiais.

Pode-se dizer que, para problemas particulares onde a utilização de algoritmos específicos é possível, "Redes Neurais são a segunda melhor maneira de fazer tudo" [21]. Sua aplicação é justificável apenas onde métodos convencionais de resolução foram falhos ou insatisfatórios. No campo prático existem aplicações de Redes Neurais Artificiais em reconhecimento de padrões, visão computacional, desenvolvimento de teoremas matemáticos, aprendizado de paradigmas e interpretações de textos, elaboração de programas computacionais e recentes pesquisas se direcionam para proteção de SEP's $[17][18][19]$. 


\section{3-Redes Neurais Artificiais e o Reconhecimento de Padrões}

Os primeiros estudos a respeito de RNA's originam dos conceitos psicológicos levantados por Aristóteles, envolvendo o cérebro humano. A representação de neurônios e suas conexões sob forma matemática é uma nova técnica, conhecida como Redes Neurais Artificiais(RNA) (ANN-do inglês "Artificial Neural Network"). Esta nova técnica biologicamente inspirada, ressurgiu após algumas décadas de seus primeiros estudos em nosso século.[22]

O cérebro humano opera de forma extremamente complexa, e faz uso de um "banco de dados" com elevado número de informações, o qual não poderia ser reproduzido fielmente por uma RNA. Todo o desenvolvimento da teoria e dos exemplos relativos a aplicação de RNA incluem modelamentos matemáticos de um neurônio extremamente simplificado. Os estudos com RNA's envolvem reconhecimento de padrões. As discussões desenvolvidas neste sentido serão particularizadas, devendo ocorrer a consulta das referências bibliográficas para maiores esclarecimentos quanto ao desenvolvimento matemático envolvido.

Deve-se levar em consideração que da mesma maneira que o cérebro deve ser treinado, mais precisamente os neurônios, para reconhecimento e análise de problemas, o mesmo deve ser feito com as RNA's. 


\section{4-Modelos de Redes Neurais Artificiais de Multicamadas}

Um dos pontos culminantes para o estudo de Redes Neurais Artificiais seria o modo como elas deveriam estar representadas, tanto matematicamente como fisicamente. A Fig. 05 mostra um dos modelos mais utilizados na representação de Redes Neurais Artificiais de multicamadas.

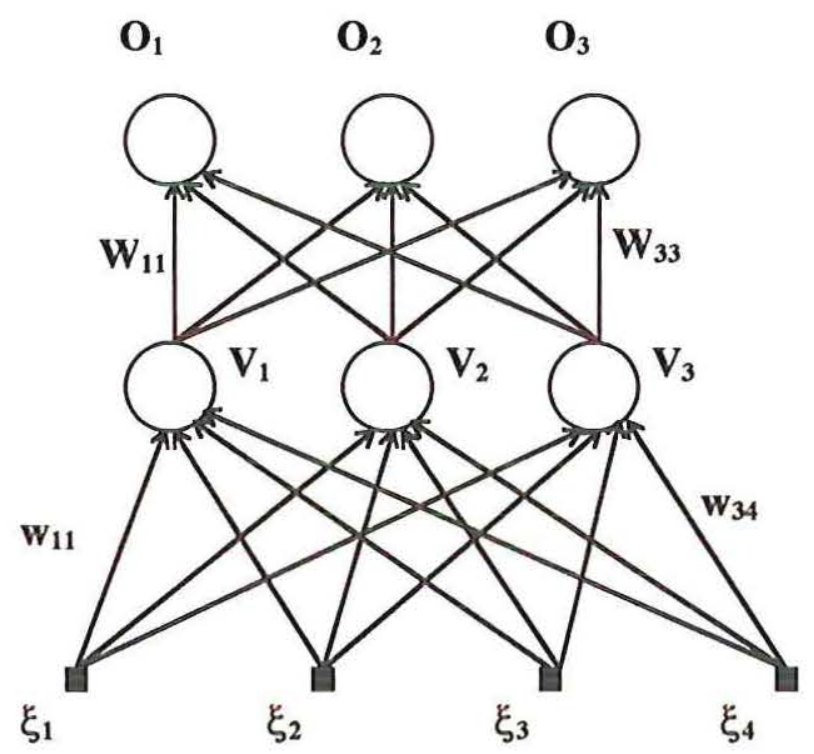

Figura 05 - Arquitetura de uma Rede Neural Artificial

Esta é conhecida por rede de "perceptrons" de duas camadas. As entradas fornecidas para a Rede Neural Artificial se encontram sob a indicação de $\xi_{\mathrm{k}}$ na Figura, onde $k$ indica o índice correspondente a entrada genérica fornecida. Os pesos $\mathrm{W}_{\mathrm{ij}}$ e $\mathrm{W}_{\mathrm{jk}}$ são os valores a serem calculados onde $i$ indica o índice onde termina a conexão, $j$ o índice de conexão de uma camada intermediária e $k$ o índice da origem da conexão. Os valores $\mathrm{O}_{\mathrm{i}}$ indicam a saída da Rede Neural Artificial, onde $i$ indica o índice da saída. 
A arquitetura conhecida por "perceptron" modela um neurônio tomando a soma ponderada de suas entradas e enviando o valor $l$ se a soma for maior que um determinado valor inicial ajustável. Caso contrário ele envia o resultado 0 . Este modelo segue os princípios de McCulloch e Pitts. Este tipo de representação foi desenvolvida por volta de 1962 por um grupo formado por Frank Rosenblatt. Este grupo buscava o melhor modo de encontrar os "pesos" apropriados, para trabalhos computacionais particulares [22].

As conexões, entre os neurônios de diferentes camadas, são representadas por linhas de ligação. Podem existir em uma RNA camadas conhecidas como "hidden layers" (camadas ocultas) cujo nome se refere a ausência de contato direto entre os dados de entrada ou saída, ocupando a posição de camadas intermediárias, com alimentação das informações encontradas nas camadas anteriores. As camadas ocultas se encontram indicadas na Fig. 05 sob a forma de $\mathrm{V}_{\mathrm{j}}$, onde $j$ representa seu índice de referência [22].

O método mais aplicado e estudado nesta última década envolve uma pesquisa inicializada a 20 anos atrás. Conhecida por "back-propagation" este método foi desenvolvido de forma mais ampla por Werbos (1974) [22]. Este algoritmo mostrou-se bastante eficaz no ajuste de valores dos "pesos" em unidades neurais (neurônios artificiais) presentes em "perceptrons" de multi-camadas sucessivas. Ele utiliza a realimentação dos valores. Assim todas as camadas, inclusive as camadas ocultas, recebem informações com relação ao comportamento da rede segundo uma relação entre os dados de entrada e de saída da RNA. Esta idéia visa organizar um treinamento eficiente da RNA. 


\section{5-O Método de "Back-propagation"}

O método de "back-propagation" foi desenvolvido por diversas vezes e diferentes pessoas, Bryson e Ho em 1969, Werbos em 1974, Parker em 1985 e Rumelhart, Hinton e Willians em 1986. O método de "back-propagation" visa fornecer os valores dos pesos $\mathrm{W}_{\mathrm{ij}}$, através do processo matemático de gradiente descendente. $\mathrm{O}$ método do gradiente descendente é aplicado através da definição de uma função de erro utilizada, ou função de custo. Esta função deverá ser minimizada e isto ocorre de modo a obter um ajuste para o par de entrada/saída fornecida a rede neural [22].

Observando a Fig. 05, pode-se tomar o par entrada/saída correta por $\xi_{\mathrm{k}}{ }^{\mu}$ e $\zeta_{\mathrm{k}}{ }^{\mu}$. Como o processo de aplicação da RNA é interativo, o índice $\mu$ indicaria o número da interação corrente. Pode-se realizar um equacionamento a partir do modelo apresentado e obter uma relação entre os termos presentes no modelo e os valores do par entrada/saída. O equacionamento e o resultado final se encontram apresentados em (3) [22].

$$
\begin{aligned}
& h_{j}^{\mu}=\sum_{k} w_{j k} \xi_{k}^{\mu} \\
& V_{j}^{\mu}=g\left(h_{j}^{\mu}\right)=g\left(\sum_{k} w_{j k} \xi_{k}^{\mu}\right) \\
& h_{i}^{\mu}=\sum_{j} W_{i j} V_{j}^{\mu}=\sum_{j} W_{i j} g\left(\sum_{k} w_{j k} \xi_{k}^{\mu}\right) \\
& \text { obtemos: } \\
& O_{i}^{\mu}=g\left(h_{i}^{\mu}\right)=g\left(\sum_{j} W_{i j} V_{j}^{\mu}\right)=g\left(\sum_{j} W_{i j} g\left(\sum_{k} w_{j k} \xi_{k}^{\mu}\right)\right)
\end{aligned}
$$


Omitidos os valores de ajuste de modo a facilitar a utilização das equações, o próximo passo é a aplicação de um método para diminuir o erro entre a saída calculada com os pesos presentes na RNA $\left(\mathrm{O}_{i}{ }^{\mu}\right)$ e os valores reais almejados $\left(\zeta_{i}{ }^{\mu}\right)$. Então, utilizando-se (3) é possível adaptar a "função de custo" sendo um dos métodos para se calcular o valor de erro, ao equacionamento da RNA. A aplicação da equação de erro é observada em (4).

de:

$E[w]=\frac{1}{2} \sum_{\mu i}\left[\zeta_{i}^{\mu}-O_{i}^{\mu}\right]^{2}$

obtemos:

$E[w]=\frac{1}{2} \sum_{\mu i}\left[\zeta_{i}^{\mu}-g\left(\sum_{j} W_{i j} g\left(\sum_{k} w_{j k} \xi_{k}^{\mu}\right)\right)\right]$

Como (4) é claramente uma função diferenciável para todos os pesos, é possível utilizar o algoritmo do gradiente descendente, visando minimizar o valor do erro, para que ocorra o "aprendizado" dos valores dos pesos. Após a aplicação do método do gradiente descendente obtemos (5), fornecendo o pequeno ajuste $\Delta \mathrm{W}_{\mathrm{ij}}$ que será acrescido ao peso $\mathrm{W}_{\mathrm{ij}}$ visando diminuir o erro $\mathrm{E}[\mathrm{w}]$.

$$
\begin{aligned}
& \Delta W_{i j}=-\eta \frac{\partial E}{\partial W_{i j}}=\eta \sum_{\mu}\left[\zeta_{i}^{\mu}-O_{i}^{\mu}\right] g^{\prime}\left(h_{i}^{\mu}\right) V_{j}^{\mu}=\eta \sum_{\mu} \delta_{i}^{\mu} V_{j}^{\mu} \\
& \text { onde: } \delta_{i}^{\mu}=g^{\prime}\left(h_{i}^{\mu}\right)\left[\zeta_{i}^{\mu}-O_{i}^{\mu}\right]
\end{aligned}
$$

Os valores de $\eta$ são fornecidos de forma a diminuir o valor de $\Delta \mathrm{W}_{\mathrm{ij}}$. A quantidade de operações realizadas é proporcional a quantidade de conexões. A existência de $n$ conexões implica na realização de $n$ operações da "função de custo". O cálculo de 
derivadas implicaria em $n^{2}$ operações. Em contraste, a aplicação do método de "backpropagation" possibilita o cálculo de $n$ derivadas em $n$ operações. Para a utilização da função de ativação $\mathrm{g}(\mathrm{h})$ presentes em (3),(4) e (5), é normal a utilização de uma função diferenciável em toda sua extensão. Pode-se utilizar equações cujos valores estarão entre 0/1 como em (6), conhecida como função logística, ou entre \pm 1 como em (7), conhecida por função tangente hiperbólica [22].

$$
\begin{aligned}
& g(h)=f_{\beta}(h)=\frac{1}{1+e^{-2 \beta h}} \\
& g(h)=\tanh \beta h
\end{aligned}
$$

Os parâmetros $\beta$, presentes em (6) e (7), são ajustados para valores 1 ou $1 / 2$.

Os passos a serem seguidos pelo método de "back-propagation" podem ser resumidos a seguir. Tomemos os valores de $W_{i j}{ }^{m}$ como a conexão entre $V_{j}^{m-1} a V_{i}^{m}$, onde $m$ indica a posição na camada.

(1) Inicialização dos valores dos pesos, através de valores aleatórios gerados. Os pesos iniciais deverão ser de pequenos valores, números aleatórios entre 0 e $I$ são normalmente aplicados a estes casos.

(2) Escolhe-se um valor de $\xi_{\mathrm{k}}{ }^{\mu}$ utilizado no treinamento e aplica-se a camada de entrada $(\mathrm{m}=0)$. Então $\mathrm{V}_{\mathrm{k}}{ }^{0}=\xi_{\mathrm{k}}{ }^{\mu}$ para todos os valores de $k$.

(3) Propaga-se o sinal para toda a RNA utilizando-se de (8). Para cada valor de $i$ e $m$ até que o valor final da saída $\mathrm{V}_{\mathrm{i}}^{\mathrm{M}}$ tenha sido calculado. 


$$
V_{i}^{m}=g\left(h_{i}^{m}\right)=g\left(\sum_{j} w_{i j}^{m} V_{j}^{m-1}\right)
$$

(4)Calcula-se os valores de $\delta$ para as camada de saída, através de (9), comparando-se o valor da atual saída $\mathrm{V}_{\mathrm{i}}^{\mathrm{M}}$ com a desejada $\zeta_{\mathrm{i}}{ }^{\mu}$ para a interação $\mu$ utilizada. O processo é interrompido se for atingido um erro considerado satisfatório.

$$
\delta_{i}^{m-1}=g^{\prime}\left(h_{i}^{m-1}\right) \sum_{j} w_{j i}^{m} \delta_{j}^{m}
$$

(5) Computa-se os valores dos $\delta_{i}$ das camadas precedentes, propagando-se o erro para trás, utilizando-se (9). Utiliza-se estas equações para $m=M, M-1, \ldots, 2$ até que todos os valores de delta tenham sido calculados para cada peso.

(5)Utiliza-se (10) para a atualização dos valores dos pesos onde teremos os novos valores para cada peso sendo $\mathrm{W}_{\mathrm{ij}}^{\text {novo }}=\mathrm{W}_{\mathrm{ij}}^{\text {anterior }}+\Delta \mathrm{W}_{\mathrm{ij}}$.

$$
\Delta W_{i j}^{m}=\eta \delta_{i}^{m} V_{j}^{m-1}
$$

(7)Retorna-se para (2) e inicia-se a nova interação.

Existem ainda muitas variações no método, para aumentar a eficiência da utilização do "back-propagation", tais como a aplicação de um "momentum" [22][23]. Neste trabalho foi utilizado o "momentum" cuja função é fornecer alguma "inércia" ao método, fazendo com que seja tomada uma média para o cálculo do próximo valor a ser 
utilizado, isto visa atenuar a ocorrência de oscilações divergentes, fazendo com que seja possível, em algumas situações, acelerar ou mesmo ocasionar a convergência. É possível ainda a utilização de diversas técnicas para otimizar o método de "back-propagation", evitando-se dificuldades (como a de se conseguir uma convergência mais rápida), dentre elas destacam-se: variações dos parâmetros internos utilizados para aplicação do método, aplicação de diferentes técnicas de convergência, etc.

3.6-Redes Neurais Artificiais Utilizando o Método de "Back-Propagation" na Simulação de um Relé de Distância

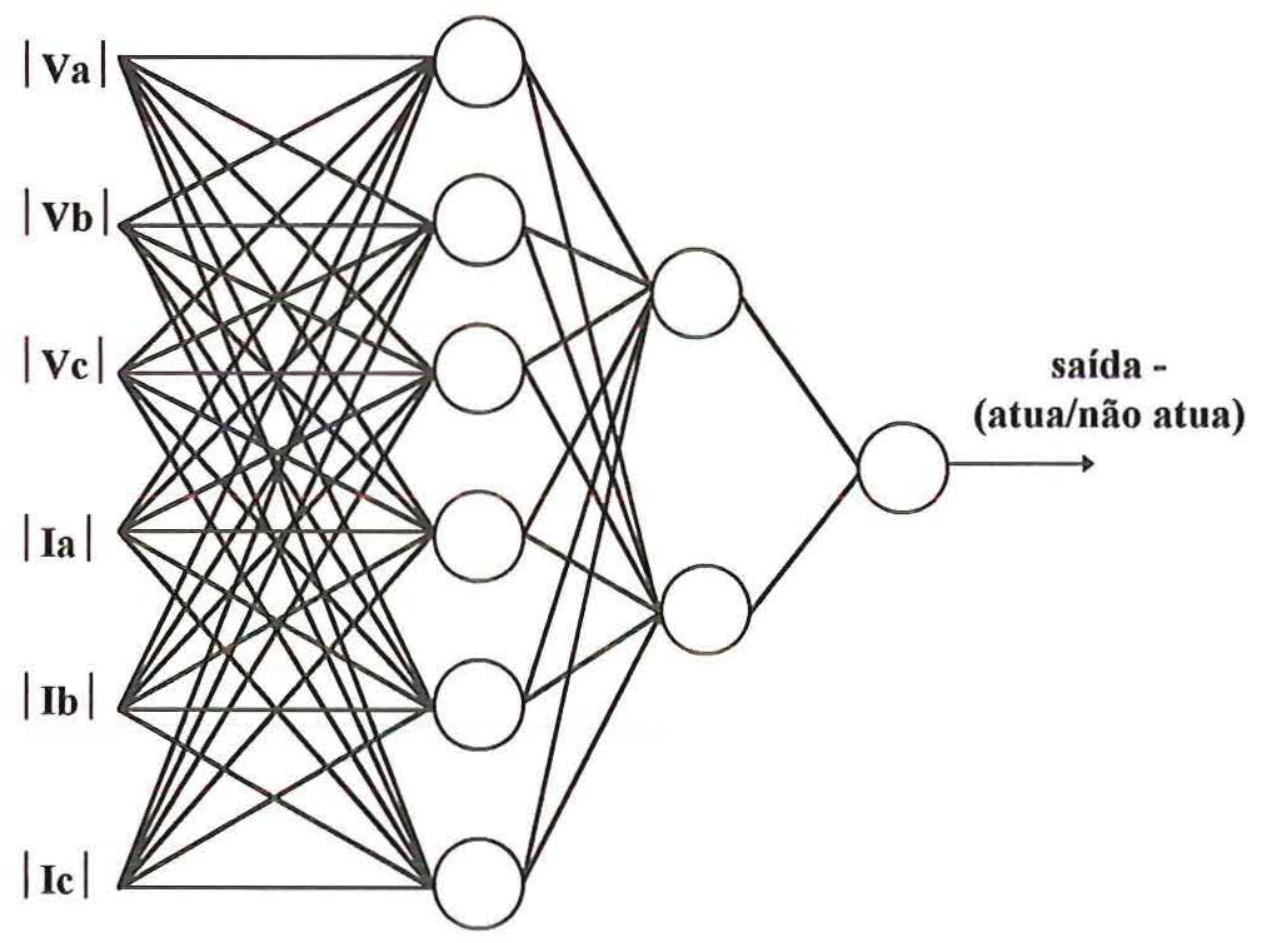

Figura 06-Uma arquitetura de Rede Neural Artificial utilizada como relé de distância

Um algoritmo convencional para um relé de distância digital utiliza as formas de onda de corrente e tensão para calcular a impedância aparente entre o barramento e o 
ponto onde ocorreu a falta, e então determinar se a falta é interna ou externa a "zona de proteção" do relé, conforme descrito no capítulo anterior.

Este trabalho propõe a utilização de RNA's de modo a simular um relé de distância, com o emprego do método de "back-propagation". A RNA atuando como um relé de distância deverá identificar a localização de faltas na primeira "zona de proteção" de uma LT (que abrange $80 \%$ da extensão da LT). As RNA's utilizam como entrada os módulos dos fasores de tensão e corrente na freqüência fundamental das três fases (Fig. 06) obtidos do $1 / 2$ ciclo de "pós-falta", de um dos barramentos da LT. Para se obter os valores dos módulos e ângulos destas formas de onda, a Transformada Discreta de Fourier (DFT) de meio ciclo foi utilizada. Desta maneira, com a informação dos valores de corrente e tensão das três fases, a RNA deverá discriminar entre faltas dentro de $80 \%$ da extensão da LT a partir do barramento, e faltas externas a esta "zona de proteção", fornecendo os valores 0 e $l$ como respostas identificando as duas situações anteriormente citadas. Para faltas internas a $80 \%$ da LT o relé deverá enviar um sinal para a chave que controla a abertura do sistema de proteção, ordenando sua atuação. $\mathrm{O}$ relé será considerado seguro se atuar apenas dentro desta "zona de proteção".

Deve ser mencionado que as variáveis de entrada devem estar normalizadas de modo a controlar a entrada das RNA's entre \pm 1 . Devido as diferentes escalas de tensão e corrente, a normalização dos valores de corrente devem ser divididos por um fator adicional.

A arquitetura da RNA, em relação a parâmetros como: número de entradas da RNA, número de neurônios na camada de entrada e nas "camadas ocultas", foi obtida de forma empírica. Este processo envolveu a utilização de diversos modelos de RNA's. Também cabe salientar que problemas surgiram durante o treinamento das RNA's. Devido a diversos fatores algumas RNA's não convergiram e foi necessário a troca de 
parâmetros para seu treinamento. A forma de treinamento, os valores iniciais dos pesos, o número de casos utilizados para o treinamento, entre outros fatores afetam os resultados das RNA's e serão discutidas no próximo capítulo.

A utilização de RNA's como relés de distância resulta em um considerável avanço para um correto diagnóstico na operação da proteção. A RNA pode resolver os problemas decorrentes da variação do alcance da "zona de proteção", citado anteriormente, muito comum em relés de distância convencionais.

\section{7-O "Hardware" Necessário para Implementação do Relé Proposto}

A Fig. 07 mostra um diagrama esquemático para o "hardware" necessário a implementação da RNA, presente em um relé de distância digital. Os sinais de corrente e tensão são obtidos da LT, passam por filtros analógicos e são condicionados para a realização das medidas. Os sinais são amostrados e digitalizados utilizando conversores Analógico/Digital (A/D). Os valores digitalizados das grandezas são então fornecidos ao microcomputador. A etapa inicial do "software" é a detecção da falta. No caso da falta existir, os sinais de tensão e corrente são enviados para filtros baseados na Transformada de Fourier de meio ciclo para extração dos fasores fundamentais. Como mencionado anteriormente, as magnitudes dos fasores (corrente e tensão) são as entradas da RNA proposta. Os pesos resultantes da etapa de treinamento são armazenados no microcomputador para aplicação "on-line". O esquema trabalha a uma taxa de $4 \mathrm{kHz}$.

Com relação ao tempo de resposta do algoritmo, é estimado que a RNA sozinha introduziria um tempo de processamento serial da ordem de $11 \mu$ s para a arquitetura mostrada na Fig. 06, considerando um microcomputador Pentium de 90MHz. É 
estimado para todos os casos estudados e apresentados no próximo capítulo, considerando o uso da DFT (ou para diminuir mais o tempo o uso de uma FFT) que o relé opera em menos de $11 \mathrm{~ms}$ após a ocorrência da falta.

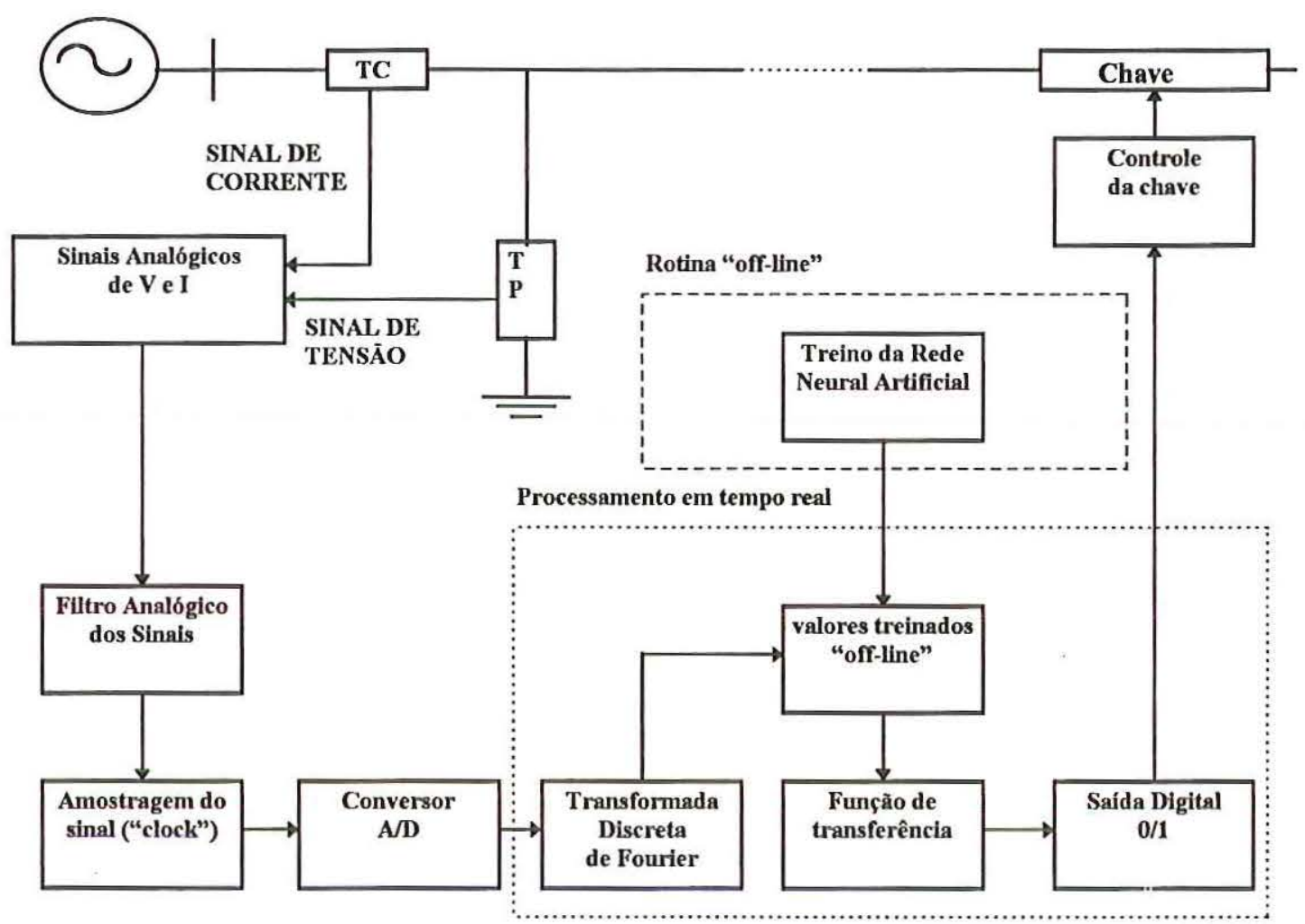

Figura 07 - Diagrama de blocos de um relé de distância baseado em RNA 


\section{4-SIMULAÇÃO E TESTES DE UM RELÉ BASEADO EM REDES NEURAIS ARTIFICIAIS}

\section{1-Descrição do Problema e Parâmetros das Arquiteturas das RNA's}

De modo a testar a aplicabilidade do sistema proposto anteriormente, as simulações de uma LT em condições faltosas são necessárias. Este trabalho utiliza-se de um simulador digital de faltas em LT's de Extra Alta Tensão (EAT) desenvolvido por Johns e Aggarwal (TEER) [24], e maiores detalhes do "software" são fornecidos no Apêndice I. Cabe também salientar que apesar dos estudos desenvolvidos serem baseados em simulações computacionais, considerações práticas como: efeitos de transdutores, filtros analógicos, quantização, entre outros estão inclusos no "software" de simulação, portanto os dados obtidos são muito próximos aos encontrados na prática.

A Fig. 08 (a) representa a LT considerada para o treinamento e teste das RNA's. Trata-se de uma LT de $400 \mathrm{kV}(60 \mathrm{~Hz})$ e $100 \mathrm{~km}$ de extensão. A Fig. 08 (b) representa o arranjo físico dos condutores, incluindo o cabo pára-raio. 


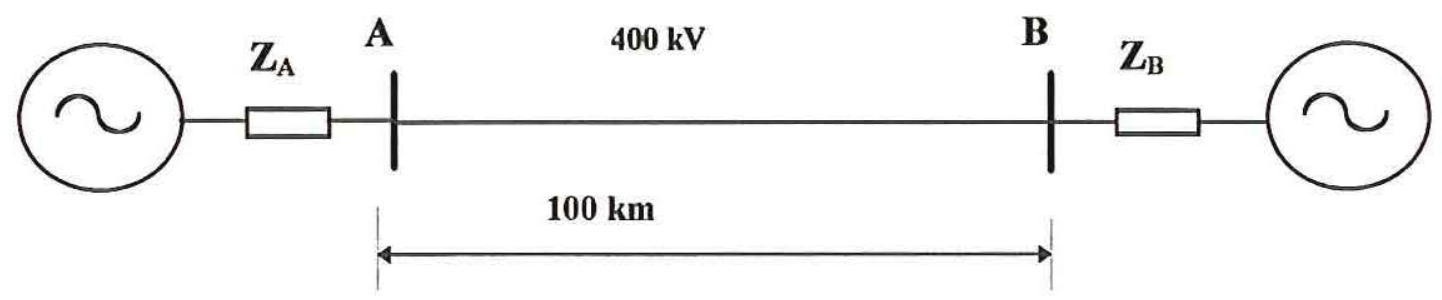

(a) Linha de Transmissão considerada nos estudos

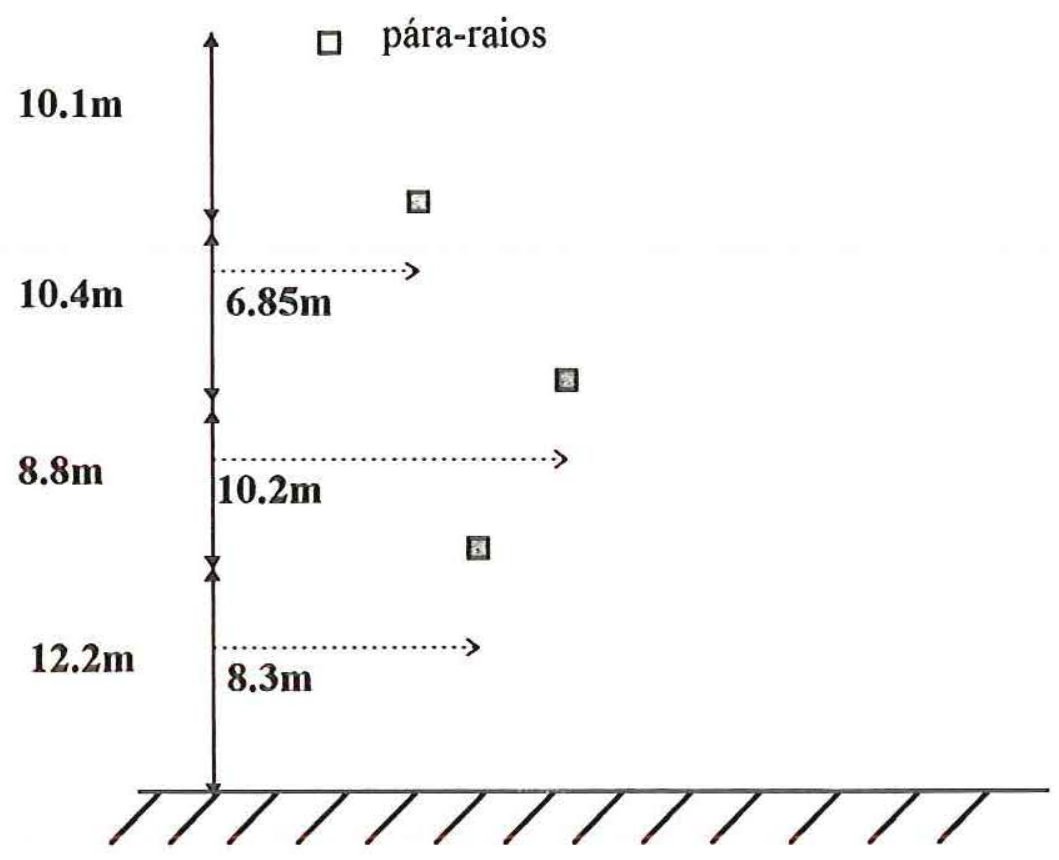

(b) Arranjo físico dos condutores da Linha de Transmissão.

Figura 08 - Modelo da Linha de Transmissão.

O software "Matlab" com o aplicativo "Neural Network Toolbox" foi utilizado para criar o diagrama da RNA, treiná-lo e obter os pesos como saída [23].

Diferentes casos de faltas em várias localizações da LT foram utilizados para treinar e testar a arquitetura de rede proposta. Várias condições de falta, bem como 
condições operacionais distintas foram incluídas. Para o estudo em questão somente faltas do tipo fase a-terra foram consideradas.

Como citado anteriormente, o objetivo da RNA é discriminar o ponto de ocorrência da falta. A proteção deverá atuar se este ponto faltoso estiver incluído dentro de $80 \%$ do comprimento da LT, a partir do barramento A. Nos modelos utilizados esta distância é de $80 \mathrm{~km}$. Caso a falta seja externa a estes $80 \%$, ou seja na faixa entre $80 \mathrm{~km}$ e $100 \mathrm{~km}$ nos modelos utilizados, não deverá ocorrer operação da proteção. Para definir a área de atuação da proteção, foi suposta uma saída binária, para determinar se a região onde ocorreu a falta é interna aos $80 \mathrm{Km}$ ou não. Caso a falta seja interna a proteção deverá atuar e a saída adotada como padrão para a RNA é de 0 , se porém a falta ocorrer externamente a zona citada a saída da RNA deverá ser 1 , e a proteção não deverá atuar. Todos os modelos utilizados foram treinados com RNA's supervisionadas. As RNA's foram treinadas pelo método de "back-propagation" convencional. Em alguns casos foram utilizados artificios matemáticos para otimizar ou acelerar a convergência das RNA's.

As arquiteturas de RNA's utilizam como dados de entrada os valores fundamentais filtrados dos módulos da tensão e corrente das três fases obtidos através de um filtro DFT, sendo estes dados provenientes do primeiro ciclo faltoso no barramento A, como citado anteriormente. Estes valores são divididos por $10^{-6}$ para os valores de tensão e $10^{-4}$ para os valores de corrente, possibilitando valores numéricos normalizados a serem operados pela RNA. A primeira arquitetura utilizada como teste para confirmar a aplicabilidade e eficiência das RNA's utilizou uma DFT de um ciclo de pós-falta, as demais arquiteturas utilizaram DFT's de $1 \frac{1}{2}$ ciclo de pós-falta. Uma descrição mais detalhada do filtro de Fourier é apresentada no Apêndice II. Todas as arquiteturas desenvolvidas fizeram uso da função logística sigmoidal como função de transferência 
dos neurônios. Esta função apresenta valores de saída entre 0 e 1 , como citado anteriormente. $\mathrm{O}$ treinamento obedeceu uma seqüência de saídas binárias $(0$ ou $I)$ para definir a atuação ou não da proteção. Os valores obtidos nos testes, quando aplicados os pesos resultantes do treinamento deverão ser adotados da seguinte forma: saída entre [00.5] ocorre a atuação da proteção, saída de $70.5-1.0]$ não ocorre a atuação da proteção. No entanto, as tabelas mostram os valores exatos, apresentados pela saída das RNA's.

O programa de simulação computacional da LT, TEER, permite uma ampla variação dos parâmetros de falta e condições operacionais da linha como explicitado no Apêndice I. No entanto, a complexidade de representação da variação de tais parâmetros foi feita de forma gradual, ou seja, modelos mais simples foram considerados inicialmente. Os primeiros modelos utilizaram como variação apenas o ponto de ocorrência da falta na Linha de Transmissão. Os estudos seguintes consideraram variações nos valores de resistência de falta ( $R$ f), ângulo de incidência da falta $\mathrm{e}$ variações no ponto de operação da linha. As arquiteturas obtidas para as RNA's a cada avanço na implementação de um modelamento mais complexo da Linha de Transmissão foram distintos. Cada caso foi estudado separadamente e concluídos apenas quando encontrados resultados satisfatórios. A obtenção das arquiteturas finais é empírica, tomando-se um tempo considerável para obtenção das formas finais das RNA's. O terceiro modelo de LT apresentado é muito próximo da situação encontrada na prática. 


\section{2-Primeira Arquitetura de RNA, Utilizando Modelo de uma LT com a Variação} Apenas da Distância do Ponto da Falta

Foi utilizada a arquitetura da Fig. 08 no primeiro estudo de RNA, utilizando-se $\mathrm{Va}=1 \angle 0^{\circ} \mathrm{pu}$, com capacidade da fonte $\mathrm{A}$ de $20 \mathrm{GVA}$ e $\mathrm{Vb}=1 \angle 0^{\circ} \mathrm{pu}$, com capacidade da fonte B de 5GVA. Não ocorre portanto fluxo de carga no modelo considerado. A arquitetura de RNA utilizada para simular um relé de distância para o circuito representado na Fig. 08, é formada apenas por uma camada de entrada de 6 neurônios, uma intermediária de 6 neurônios e uma saída com apenas um neurônio, visualizada na Fig. 09. A arquitetura recebeu treinamento com 12 situações diferentes de falta na LT. O valor de $\mathrm{Rf}$ foi mantido constante no valor de $10 \Omega$, o ângulo de incidência da falta também constante em $90^{\circ}$ e os demais parâmetros físicos da Linha de Transmissão também foram mantidos inalterados. Para o treinamento deste modelo foram realizadas apenas variações da distância onde ocorreu a falta, sendo sete casos distintos com falta interna aos $80 \mathrm{~km}$ e cinco casos distintos com faltas externas aos $80 \mathrm{~km}$. Para treinar a RNA proposta na Fig. 09 foi utilizado o método de "back-propagation" convencional, descrito com pormenores anteriormente. A convergência foi obtida após 10000 interações. As arquiteturas utilizadas possuem um "bias" para o cálculo dos pesos. Este primeiro modelo da LT visava observar com maiores detalhes a eficiência do método, e a flexibilidade do mesmo. O tempo para se obter a convergência foi de 12 horas em um microcomputador PC 486-DX2. 


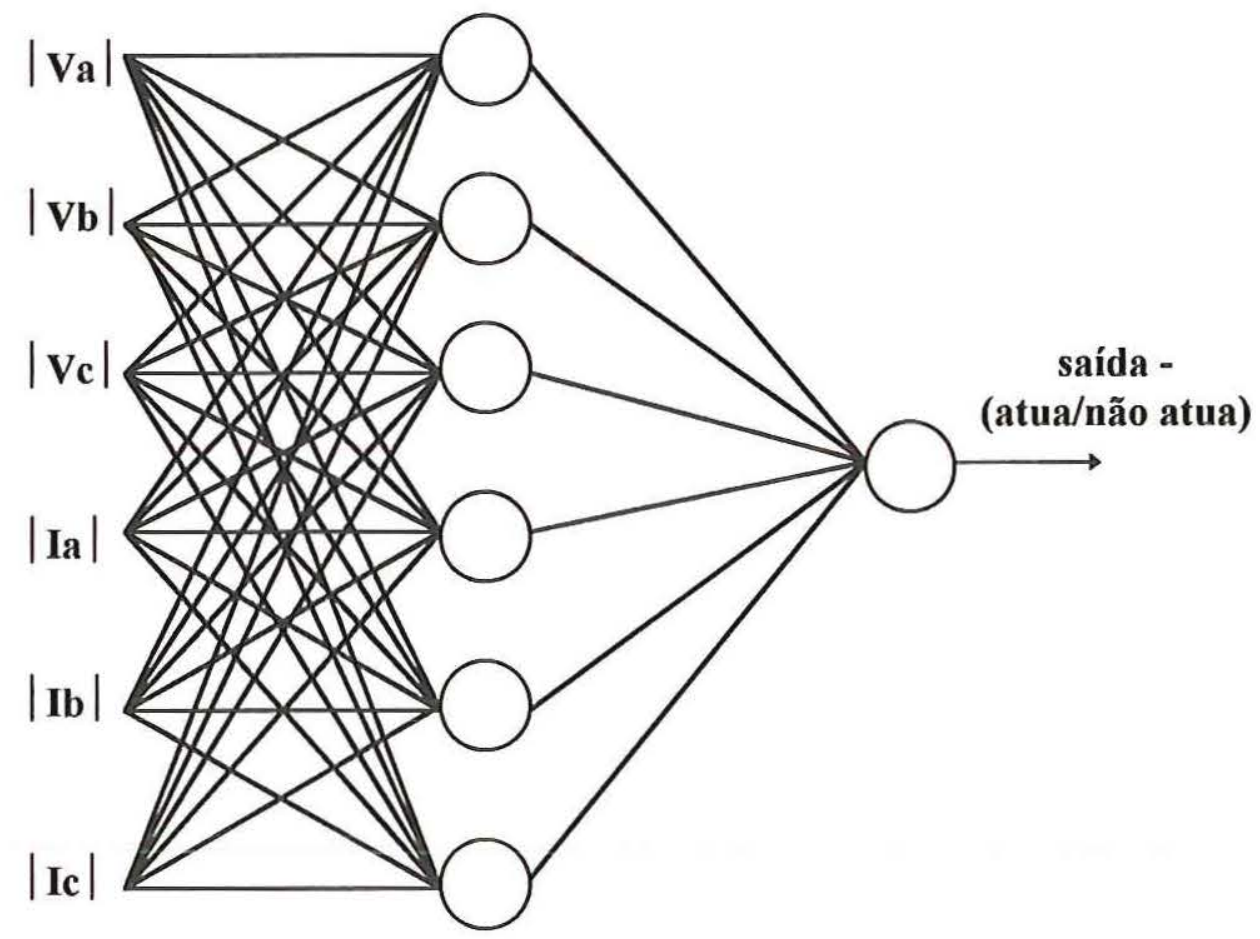

Figura 09 - Arquitetura da RNA, com dados de treinamento incluindo apenas a variação da distância da falta. Aplicada ao modelo da LT da Fig. 08.

Os valores de saída da RNA, após o treinamento, podem ser obtidos como indicado em (12). A Tabela 01 mostra os resultados obtidos com valores não utilizados no treinamento. A resposta da RNA pode ser comparada com a saída esperada para cada caso e o poder de generalização da rede pode ser comprovado. Os valores são resultantes da utilização dos pesos calculados após o treinamento atingir um valor de erro médio quadrático inferior a $10^{-2}$.

$$
S=g\left(\sum_{j=1}^{6} W_{j}\left(g\left(\sum_{k=1}^{6} w_{j k} \xi_{k}+b_{j}\right)+B\right)\right.
$$


onde:

S - saída fornecida pela RNA.

w - valores dos pesos calculados, da primeira camada (entrada).

W - valores dos pesos calculados, da segunda camada (saída).

$\mathrm{g}$ - função empregada na RNA, logística para este caso.

b - valores de ajuste ("bias") calculados, da primeira camada.

B - valor de ajuste ("bias") calculado, da segunda camada.

$\xi$ - valor numérico fornecido como entrada para a RNA.

Durante o treinamento é realizado a inicialização dos valores dos pesos por um princípio aleatório, sendo estes valores escolhidos entre 0 e 1 para todos os pesos. Todos os valores de distâncias visualizados na Tabela 01 não foram utilizados para o treinamento. Os resultados apresentados possuem um índice de acerto de $100 \%$.

A arquitetura utilizada para o treinamento sofreu variações apenas da distância da falta, como citado anteriormente. Para avaliar o desempenho da RNA para pequenas variações foram realizados novos testes empregando os mesmos valores de pesos encontrados durante o treinamento, porém foram implementadas pequenas variações nos parâmetros da LT. Para pequenas variações nos parâmetros o comportamento de uma LT, em uma situação faltosa, se mantém próximo aos valores anteriores a estas variações. A Tabela 02 apresenta os resultados após algumas pequenas variações nos parâmetros da LT estudada, e as respostas obtidas utilizando-se os valores dos pesos inicialmente encontrados no treinamento da RNA.

Pode-se notar que as respostas são satisfatórias. Os pontos assinalados com um asterisco (*) indicam erro nos resultados. Os erros encontrados foram apenas em casos cuja resistência de falta utilizada era demasiadamente pequena, o que gera elevação dos valores da corrente pós-falta e conseqüentemente os resultados obtidos são muito diferentes daqueles utilizados durante o treinamento da Linha de Transmissão. Pode-se verificar a existência de uma flexibilidade na RNA após o treinamento, mediante os 
resultados da Tabela 02 . No entanto, pode-se concluir que um modelo de variação de parâmetros mais complexo se faz necessário na geração de dados para treinamento relativos a uma LT de alta-tensão. 


\begin{tabular}{|c|c|c|c|c|c|}
\hline $\begin{array}{c}\text { Distância da } \\
\text { falta ao } \\
\text { ponto } A \\
(\mathrm{~km}) \\
\end{array}$ & $\begin{array}{c}\text { Resposta da } \\
\text { RNA }\end{array}$ & $\begin{array}{c}\text { Resposta } \\
\text { correta }\end{array}$ & $\begin{array}{c}\text { Distância } \\
\text { da falta ao } \\
\text { ponto A } \\
\text { (km) } \\
\end{array}$ & $\begin{array}{c}\text { Resposta da } \\
\text { RNA }\end{array}$ & $\begin{array}{c}\text { Resposta } \\
\text { correta }\end{array}$ \\
\hline 2.0 & 1 & 1 & 56.0 & 1 & 1 \\
\hline 4.0 & 1 & 1 & 60.0 & 1 & 1 \\
\hline 6.0 & 1 & 1 & 61.0 & 1 & 1 \\
\hline 8.0 & 1 & 1 & 64.0 & 1 & 1 \\
\hline 10.0 & 1 & 1 & 65.0 & 1 & 1 \\
\hline 11.0 & 1 & 1 & 68.0 & 1 & 1 \\
\hline 13.0 & 1 & 1 & 71.0 & 1 & 1 \\
\hline 16.0 & 1 & 1 & 73.0 & 1 & 1 \\
\hline 20.0 & 1 & 1 & 74.0 & 1 & 1 \\
\hline 22.0 & 1 & 1 & 75.0 & 1 & 1 \\
\hline 26.0 & 1 & 1 & 76.0 & 1 & 1 \\
\hline 29.0 & 1 & 1 & 77.0 & 0.9998 & 1 \\
\hline 30.0 & 1 & 1 & 78.0 & 0.9941 & 1 \\
\hline 33.0 & 1 & 1 & 82.0 & $2.6845 \mathrm{e}^{-4}$ & 0 \\
\hline 35.0 & 1 & 1 & 83.0 & $1.0104 \mathrm{e}^{-5}$ & 0 \\
\hline 37.0 & 1 & 1 & 84.0 & $4.2734 \mathrm{e}^{-7}$ & 0 \\
\hline 40.0 & 1 & 1 & 86.0 & $1.1656 \mathrm{e}^{-9}$ & 0 \\
\hline 42.0 & 1 & 1 & 87.0 & $6.6594 \mathrm{e}^{-11}$ & 0 \\
\hline 45.0 & 1 & 1 & 88.0 & $3.9977 \mathrm{e}^{-12}$ & 0 \\
\hline 46.0 & 1 & 1 & 89.0 & $2.7110 \mathrm{e}^{-13}$ & 0 \\
\hline 48.0 & 1 & 1 & 92.0 & $2.0983 \mathrm{e}^{-16}$ & 0 \\
\hline 52.0 & 1 & 1 & 94.0 & $2.8801 \mathrm{e}^{-18}$ & 0 \\
\hline 54.0 & 1 & 1 & 96.0 & $5.3289 \mathrm{e}^{-20}$ & 0 \\
\hline 55.0 & 1 & 1 & 98.0 & $1.5577 \mathrm{e}^{-21}$ & 0 \\
\hline
\end{tabular}

Tabela 01-Resultados para a RNA com arquitetura representada pela Fig. 09. 


\begin{tabular}{|c|c|c|}
\hline Parâmetros modificados & $\begin{array}{c}\text { Saída da } \\
\text { RNA }\end{array}$ & $\begin{array}{c}\text { Saída } \\
\text { correta } \\
\end{array}$ \\
\hline $\begin{array}{l}\text { Ângulo de incidência da falta de } 88^{\circ} \text {, distância da } \\
\text { falta }=75 \mathrm{~km} \text { de A. }\end{array}$ & 1 & 1 \\
\hline $\begin{array}{l}\text { Ângulo de incidência da falta de } 88^{\circ} \text {, distância da } \\
\text { falta }=85 \mathrm{~km} \text { de A. }\end{array}$ & $1.5024 .10^{-7}$ & 0 \\
\hline $\begin{array}{l}\text { Ângulo de incidência da falta de } 92^{\circ} \text {, distância da } \\
\text { falta }=70 \mathrm{~km} \text { de A. }\end{array}$ & 1 & 1 \\
\hline $\begin{array}{l}\text { Ângulo de incidência da falta de } 92^{\circ} \text {, distância da } \\
\text { falta }=85 \mathrm{~km} \text { de A. }\end{array}$ & $3.3442 .10^{-9}$ & 0 \\
\hline $\mathrm{Rf}=0 \Omega$, distância da falta $=70 \mathrm{~km}$ de $\mathrm{A}$. & 1 & 1 \\
\hline $\mathrm{Rf}=0 \Omega$, distância da falta $=90 \mathrm{~km}$ de $\mathrm{A}$. & $1 *$ & 0 \\
\hline $\mathrm{Rf}=5 \Omega$, distância da falta $=85 \mathrm{~km}$ de $\mathrm{A}$. & $1 *$ & 0 \\
\hline $\mathrm{Rf}=5 \Omega$, distância da falta $=70 \mathrm{~km}$ de $\mathrm{A}$. & 1 & 1 \\
\hline $\mathrm{Rf}=8 \Omega$, distância da falta $=70 \mathrm{~km}$ de $\mathrm{A}$. & 1 & 1 \\
\hline $\mathrm{Rf}=8 \Omega$, distância da falta $=95 \mathrm{~km}$ de $\mathrm{A}$. & $2.0047 .10^{-15}$ & 0 \\
\hline $\mathrm{Rf}=12 \Omega$, distância da falta $=70 \mathrm{~km}$ de $\mathrm{A}$. & 1 & 1 \\
\hline $\mathrm{Rf}=12 \Omega$, distância da falta $=90 \mathrm{~km}$ de $\mathrm{A}$. & $5.8528 .10^{-18}$ & 0 \\
\hline $\mathrm{Rf}=15 \Omega$, distância da falta $=70 \mathrm{~km}$ de $\mathrm{A}$. & 0.9192 & 1 \\
\hline $\mathrm{Rf}=15 \Omega$, distância da falta $=90 \mathrm{~km}$ de $\mathrm{A}$. & $1.1459 .10^{-21}$ & 0 \\
\hline Fonte B com 4.5GVA, distância da falta $=75 \mathrm{~km}$ de A. & \begin{tabular}{|l|}
1 \\
\end{tabular} & 1 \\
\hline Fonte B com 4.5GVA, distância da falta $=90 \mathrm{~km}$ de A. & $2.3569 .10^{-13}$ & 0 \\
\hline Fonte B com 4GVA, distância da falta=70km de A. & 1 & 1 \\
\hline Fonte B com 4GVA, distância da falta=90km de A. & $3.5749 .10^{-12}$ & 0 \\
\hline Fonte A com $18 \mathrm{GVA}$, distância da falta $=75 \mathrm{~km}$ de $\mathrm{A}$. & 1 & 1 \\
\hline Fonte A com $18 \mathrm{GVA}$, distância da falta $=90 \mathrm{~km}$ de $\mathrm{A}$. & $7.1024 .10^{-15}$ & 0 \\
\hline
\end{tabular}

Tabela 02-Resultados da RNA da Fig. 08 para pequenas variações nos dados de treinamento. 
4.3-Segunda Arquitetura de RNA, Utilizando Modelos de LT com a Variação de Rf e Distância da Falta na LT Considerada

Para esta situação foi adotada a mesma Linha de Transmissão da Fig. 08. A condição de operação utilizada foi $\mathrm{Va}=1.1 \angle 20^{\circ} \mathrm{pu}$, com capacidade da fonte A de 10GVA e $\mathrm{Vb}=0.9 \angle 0^{\circ} \mathrm{pu}$, com capacidade da fonte B de 5GVA. Foram mantidos os mesmos parâmetros básicos em todas as simulações. A segunda arquitetura de RNA, porém, utiliza uma configuração diferente da apresentada da primeira arquitetura e encontra-se na Fig. 10.

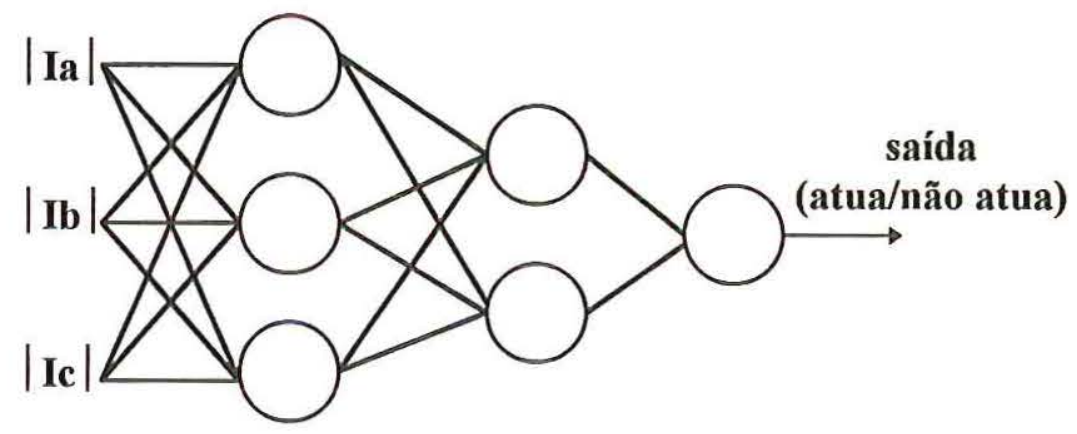

Figura 10 - Segunda arquitetura de RNA, com variação de Rf e distância da falta.

Modelo empregado para LT da Fig. 08.

A saída calculada pela RNA é fornecida por (13), empregando-se os valores dos pesos e ajuste ("bias") após o treinamento.

$$
S=g\left(\sum_{i=1}^{2} W_{i}^{\prime} g\left(\sum_{j=1}^{3} W_{i j}\left(g\left(\sum_{k=1}^{3} w_{j k} \xi_{k}+b_{j}\right)+B_{i}\right)+B^{\prime}\right)\right.
$$


onde:

S - saída fornecida pela RNA.

w - valores dos pesos calculados, da primeira camada (entrada).

W - valores dos pesos calculados, da camada oculta (intermediária).

W'- valores do pesos calculados, da terceira camada (saída).

$\mathrm{g}$ - função empregada na RNA, logística para este caso.

b - valores de ajuste ("bias") calculados, da primeira camada.

B - valor de ajuste ("bias") calculados, da camada oculta.

B'- valor de ajuste ("bias") calculado, da segunda camada.

$\xi$ - valor numérico fornecido como entrada para a RNA.

Para a arquitetura da RNA da Fig. 10 foram utilizados os valores filtrados por uma DFT de $1 / 2$ ciclo pós-falta das três correntes do barramento A (Ia,Ib e Ic), apresentadas como valores de entrada. A representação da RNA possui duas camadas intermediárias de três e dois neurônios. A arquitetura da Fig. 10 foi treinada com a utilização de "Momentum", visando otimizar a RNA. O valor utilizado como parâmetro do "Momentum" foi de 0.95 . Esta arquitetura foi considerada como a de melhor desempenho após uma seqüência de testes. Durante a tentativa de implementação de diferentes arquiteturas, foram utilizados entre outros a arquitetura anterior da Fig. 09, e variações da quantidade de entradas, assim como variações da quantidade de neurônios da camada intermediária.

O treinamento foi realizado com 286 simulações diferentes, sendo que estas possuem variações de resistência de falta de $2 \Omega$ a $85 \Omega$ e 22 distâncias para cada $R f$ diferente. Foram utilizados os valores de $\mathrm{Rf}$ de $2,5,8,10,12,15,25,35,45,55,65,75$, $85 \Omega$. Cada valor de $\mathrm{Rf}$ foi simulado com 12 distâncias abaixo de $80 \mathrm{~km}$ (atuação da proteção) e 10 distâncias acima de $80 \mathrm{~km}$ (não atuação da proteção). Assim são obtidas 22 situações vezes 13 diferentes valores de $\mathrm{Rf}$, perfazendo o total de 286 simulações. $\mathrm{O}$ tempo para convergência foi de 48 horas em um microcomputador PC 486-DX2, com 
40000 interações. $\mathrm{O}$ valor do erro médio quadrático obtido foi inferior a $10^{-3}$ para este treinamento da RNA.

Após o treinamento, os valores dos pesos e "bias" obtidos foram submetidos a uma seqüência de testes, que se encontram na Tabela 03 , com valores de $\mathrm{Rf}$ e distância da falta distintos dos utilizados para o treinamento.

A Tabela 03 possui um índice de acerto de $98.41 \%$. O único erro, assinalado com um asterisco $\left({ }^{*}\right)$, ocorrido nos testes está presente em $80 \mathrm{Km}$; sendo que nesta região ocorre uma situação de mudança de atuação para não atuação da proteção. $O$ erro ocorreu em uma situação cuja resistência de falta é extremamente baixa $\mathrm{Rf}=1 \Omega$, portanto os valores da corrente de pós-falta nesta situação são extremamente elevados. O desempenho da RNA utilizada pode ser considerada excelente. $\mathrm{O}$ modelo pode discernir com ótima precisão a região de atuação ou não da proteção utilizando apenas os valores do primeiro $1 \frac{1}{2}$ ciclo filtrado em uma DFT das correntes de pós-falta. 


\begin{tabular}{|c|c|c|c|c|}
\hline Distância ao ponto $\boldsymbol{A}(\mathbf{k m})$ & $\mathbf{R} \mathbf{f}=\mathbf{1} \Omega$ & $\mathbf{R} \mathbf{f}=\mathbf{1 7} \Omega$ & $\mathbf{R} \mathbf{f}=\mathbf{7 0} \Omega$ & Valor Correto \\
\hline \hline 4 & 0 & 0 & 0 & 0 \\
\hline 15 & 0 & 0 & 0 & 0 \\
\hline 25 & 0 & 0 & 0 & 0 \\
\hline 35 & 0 & 0 & 0 & 0 \\
\hline 45 & 0 & 0 & 0 & 0 \\
\hline 55 & 0 & 0 & 0 & 0 \\
\hline 65 & 0 & 0 & 0 & 0 \\
\hline 68 & 0 & 0 & 0 & 0 \\
\hline 76 & 0 & 0 & 0 & 0 \\
\hline 79 & 0 & 0.0008 & 0.0460 & 0 \\
\hline 80 & $0.1007 *$ & 0.9774 & 0.8529 & 1 \\
\hline 81 & 1 & 1 & 0.9981 & 1 \\
\hline 82 & 1 & 1 & 1 & 1 \\
\hline 84 & 1 & 1 & 1 & 1 \\
\hline 86 & 1 & 1 & 1 & 1 \\
\hline 88 & 1 & 1 & 1 & 1 \\
\hline 91 & 1 & 1 & 1 & 1 \\
\hline 93 & 1 & 1 & 1 & 1 \\
\hline 94 & 1 & 1 & 1 & 1 \\
\hline 95 & 1 & 1 & 1 & 1 \\
\hline 96 & 1 & 1 & 1 & 1 \\
\hline
\end{tabular}

Tabela 03-Apresentação dos testes da RNA da Fig. 09. 


\section{4-Terceira Arquitetura de RNA, Utilizando Modelo com a Variação da Resistência e Distância de Falta, Ângulo de Incidência da Mesma e da Condição de Operação Presente na LT}

Esta terceira situação visa aproximar a LT encontrada na prática com relação ao modelo adotado, para simular com maior fidelidade o funcionamento de um relé de distância. Neste modelo foi incluído no treinamento a variação de quatro parâmetros distintos: a distância da falta, a resistência de falta, o ângulo de incidência da falta e o fluxo de carga na LT. O modelo de LT utilizado foi o da Fig. 08, o mesmo adotado no itens 4.2 e 4.3 . Os valores de Va foram ajustados para $1.1 \angle 20^{\circ}$ e $1.1 \angle 15^{\circ}$, com capacidade da fonte A de 10GVA; enquanto os valores de $\mathrm{Vb}$ foram mantidos iguais a $0.9 \angle 0^{\circ}$, e capacidade da fonte B de $9.5 \mathrm{GVA}$ durante o treinamento. Para esta situação foram desenvolvidos quatro diferentes grupos de simulações, cada um deles semelhante ao utilizado no item 4.3 com 286 simulações em cada grupo. Cada grupo possuía um valor do ângulo de incidência da falta e do fluxo de carga. A variação do ângulo de incidência da falta visava ampliar a gama de aplicação dos casos possíveis dentro de um preestabelecido funcionamento da LT. A variação do fluxo de carga visa aumentar a flexibilidade do sistema para diferentes pontos operacionais da LT. Foram utilizados um total de 1144 simulações diferentes para o treinamento, quatro vezes as 286 simulações utilizadas no item 4.3. Para estas situações foram realizadas variações da distância dentro dos $100 \mathrm{~km}$ da LT. A resistência de falta, como no item 4.3, sofreu variações de $2 \Omega$ a $85 \Omega$. Tanto a variação do valor de $\mathrm{Rf}$ como da distância da falta compuseram um grupo de simulações semelhante a utilizada no item 4.3. O valor do ângulo de incidência da 
falta foi variado com os valores de $0^{\circ} \mathrm{e} 90^{\circ}$. Cada valor do ângulo de incidência de falta foi adotado para um grupo distinto de simulações, onde os parâmetros do ângulo de transferência de potência da fonte $\mathrm{A}$ foram alterados para $1.1 \angle 15^{\circ} \mathrm{pu}$ e $1.1 \angle 20^{\circ} \mathrm{pu} \mathrm{em}$ cada grupo, perfazendo um total de quatro grupos distintos.

A arquitetura de RNA utilizada para esta situação está apresentada na Fig. 11. Após diversos testes com diferentes configurações, a convergência dos valores dos pesos foi obtida com esta arquitetura.

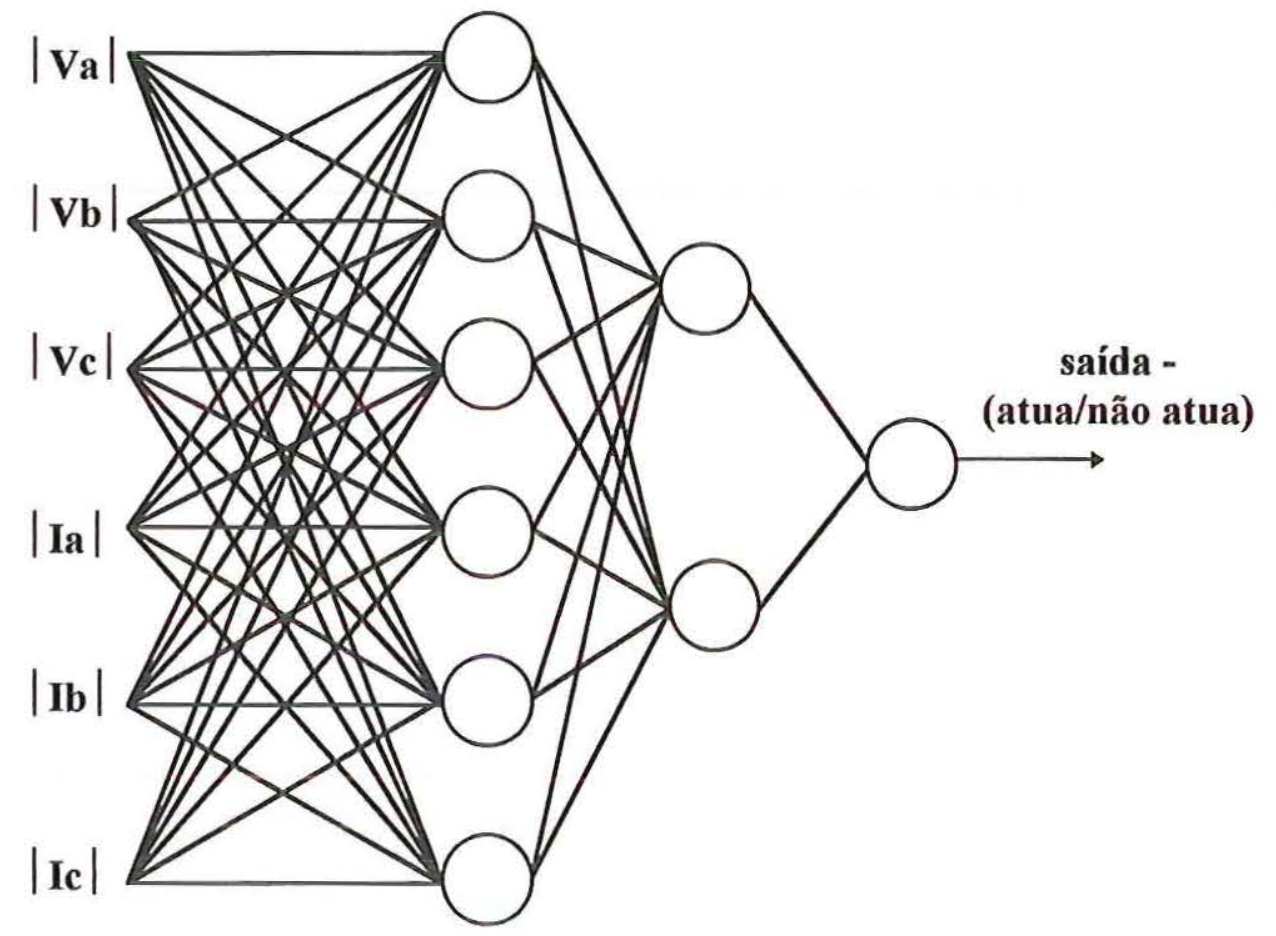

Figura 11 - Arquitetura da RNA com dados de treinamento incluindo variação dos quatro parâmetros. Modelo empregado para LT da Fig. 08.

Para o cálculo da saída da RNA da Fig. 11 utiliza-se (14), mediante a entrada dos valores fornecidos. Esta equação utiliza os valores dos pesos e "bias" calculados após o treinamento da RNA. 


$$
S=g\left(\sum_{i=1}^{2} W_{i}^{\prime} g\left(\sum_{j=1}^{6} W_{i j}\left(g\left(\sum_{k=1}^{6} w_{j k} \xi_{k}+b_{j}\right)+B_{i}\right)+B^{\prime}\right)\right.
$$

onde:

S - saída fornecida pela RNA.

w - valores dos pesos calculados, da primeira camada (entrada).

W - valores dos pesos calculados, da camada oculta (intermediária).

W'- valores do pesos calculados, da terceira camada (saída).

$\mathrm{g}$ - função empregada na RNA, logística para este caso.

b - valores de ajuste ("bias") calculados, da primeira camada.

B - valores de ajuste ("bias") calculados, da camada oculta.

B'- valor de ajuste ("bias") calculado, da segunda camada.

$\xi$ - valor numérico fornecido como entrada para a RNA.

A arquitetura faz uso dos três valores de corrente e tensão do barramento $\mathrm{A}$, obtidos a partir do fasor filtrado, através de uma DFT, de $1 / 2$ ciclo. Foi empregado o valor do "momentum" nesta simulação ajustado para 0.95 . O erro médio quadrático para esta situação foi inferior a $10^{-2}$. Foi verificada ocorrência da convergência dos pesos para uma situação de valores de entrada e saída próximos entre si de forma satisfatória, com 80000 ciclos, obtido após 24 horas de processamento em um microcomputador PC 486-DX2.

Para este modelo foram realizados diversos testes de desempenho com a variação dos parâmetros de distância da falta, resistência de falta, capacidade e impedância interna das fontes, fluxo de carga, assim como o do ângulo de incidência da falta. Os testes presentes nas Tabelas de 4 a 15 perfazem um total de mais de 600 diferentes casos não utilizados no treinamento. Os valores de distância e $\mathrm{Rf}$ são diferentes dos valores utilizados durante o treinamento. Os valores do ângulo de incidência da falta utilizado para os testes foram de $0^{\circ}, 30^{\circ}, 45^{\circ}, 60^{\circ}$ e $90^{\circ}$. Para testar se os valores de pesos 
encontrados pelo treinamento poderiam fornecer valores corretos para as duas diferentes situações de fluxo de carga utilizadas, foram realizadas simulações para ambos os casos.

Os erros encontrados nas Tabelas com relação a atuação/não atuação do relé, descrita anteriormente, estão marcados por um asterisco (*). Cabe salientar que todos os erros poderão ser encontrados próximos ao ponto onde ocorre a inversão do estado do relé, de atuação para não atuação da proteção. Em poucos casos ocorre a presença de erros em pontos externos a uma faixa entre $78 \mathrm{Km}$ a $82 \mathrm{Km}$ do ponto $\mathrm{A}$, que pode ser tomada como uma região de indeterminação para a RNA considerada.

A Tabela 04 mostra resultados de testes com um ângulo de incidência da falta de $0^{\circ}$, o qual fora utilizado para o treinamento da RNA, porém a variação dos demais parâmetros (distância e Rf) não foram utilizados no treinamento. Os resultados obtidos, com acerto de $100 \%$, demonstram a correta convergência obtida com a RNA da Fig. 11.

A Tabela 05, apresentada de forma semelhante a Tabela 04, também fornece valores aceitáveis de erro. Nesta Tabela o valor do ângulo de incidência foi de $30^{\circ}$, diferente dos dois valores utilizados para o treinamento $\left(0^{\circ}\right.$ e $\left.90^{\circ}\right)$. Um total de 3 erros ocorreram em 60 simulações distintas, perfazendo 95\% de acerto. Apesar destes erros pode-se considerar satisfatórios os resultados, haja visto que a ocorrência dos erros deuse muito próximo ao intervalo onde ocorre a mudança do estado do relé de atuação para não atuação.

A Tabela 06 ilustra a mesma situação da Tabela 05, porém com ângulo de incidência da falta de $45^{\circ}$. O índice de acerto foi de $93.33 \%$. Ocorreram 4 casos de julgamento incorreto da operação do relé, porém estes pontos se encontram também próximos ao trecho onde ocorre a mudança de operação para não operação do relé.

A Tabela 07, apresenta-se de forma semelhante as três anteriores, com ângulo de incidência de falta de $60^{\circ}$. Como nas situações anteriores os erros se encontram 
próximos ao ponto de mudança do estado do relé. Com estes valores pode-se notar um índice de acerto de $95 \%$.

A Tabela 08 apresenta resultados com os valores semelhantes as quatro Tabelas anteriores, com o valor do ângulo de incidência da falta de $90^{\circ}$. Como é possível observar o índice de acerto é de $100 \%$. O valor do ângulo de incidência da falta é um dos utilizados para o treinamento da RNA, os valores encontrados podem ser considerados excelentes.

O desempenho do relé apresentado nas Tabelas 04, 05, 06, 07 e 08 para a situação do barramento $\mathrm{A}$ com $1.1 \angle 15^{\circ}$ são de alta eficiência. Em 300 diferentes simulações ocorreram um total de 10 erros, portanto o índice de acertos foi de $96.67 \%$. Deve-se observar também que todos os erros ocorreram próximos ao trecho de inversão do estado do relé.

A Tabela 09 apresenta resultados para uma situação com fluxo de carga diferente do utilizado nas Tabelas de 04 a 08, para um ângulo de incidência de falta de $0^{\circ}$. Apresentando apenas um erro, o índice de acerto é de $98.33 \%$. O erro, da mesma forma que os presentes nas cinco tabelas anteriores, encontra-se próximo ao ponto de mudança do estado do relé.

A Tabela 10 contém 4 erros dos 60 casos apresentados, perfazendo um índice de acerto de $93.33 \%$. A Tabela 10 apresenta resultados para um ângulo de incidência da falta de $30^{\circ}$, diferente dos valores utilizados para o treinamento da RNA.

Na Tabela 11 apresentam-se 5 erros, no desempenho do relé considerado, entre os 60 casos propostos. O índice de acerto é de $91.67 \%$, menor que os demais encontrados nas Tabelas de 4 a 10. Pode-se constatar que, no entanto, a região onde ocorrem os erros ainda é muito próxima a faixa onde ocorre a inversão do estado do relé. $\mathrm{O}$ ângulo de $45^{\circ}$ não foi incluído entre os valores $\left(0^{\circ}\right.$ e $\left.90^{\circ}\right)$ utilizados para 0 
treinamento da RNA. Os erros encontrados na Tabela se localizam em sua grande maioria quando o valor de $\mathrm{Rf}$ é de $70 \Omega$. Este valor de $\mathrm{Rf}$ pode ser considerado elevado. Consultando os valores de $\mathrm{Rf}$ utilizados para o treinamento da RNA verifica-se que os valores próximos a $85 \Omega$ (o extremo dos valores de Rf) foram treinados com uma menor esparcidade.

Na Tabela 12 (ângulo de incidência de falta de $60^{\circ}$ ) estão expressos 7 erros, diminuindo o índice de acerto da RNA para $88.33 \%$. Pode-se verificar que os valores ainda se encontram apenas na região próxima a mudança do estado do relé. Porém um fato que desperta a atenção é a incidência de erros apenas em valores de elevada resistência de falta.

A Tabela 13, considerando um ângulo de incidência de $90^{\circ}$, apresenta um índice de acerto de $100 \%$. Apesar da ocorrência de valores diferentes dos valores binários, obtidos com os pesos calculados da RNA, a consideração de atuação (0) e não atuação (1) da proteção segue o princípio estabelecido para o sistema anteriormente citado: valores entre [0-0.5] o relé atuará e valores entre ]0.5-1] o relé não irá atuar.

A Tabela 14 apresenta os resultados da RNA após a variação da capacidade da fonte A (originalmente de 10GVA), da LT da Fig. 08. O valor de Rf utilizado foi de $17 \Omega$, para todos os testes. Pode ser verificado que, uma variação na capacidade da fonte não influi excessivamente no desempenho do relé. As falhas de atuação ocorrem próximas a região de inversão do estado do relé. $O$ índice de acerto do relé, com variações na capacidade da fonte A, foi de $96.25 \%$.

O último parâmetro que foi modificado para testar o desempenho da RNA, com relação a um relé industrial convencional (digital ou analógico) foi a modificação da relação entre as impedâncias das fontes. $O$ parâmetro $Z_{a} / Z_{b}$ da fonte $A$ da Fig. 08 foi mantido constante e igual a 1 , durante todo o treinamento e testes realizados nas Tabelas 
anteriores. Esta relação foi modificada para 3 diferentes situações e foi gerada a Tabela 15. O valor de $\mathrm{Rf}$ foi mantido a $17 \Omega$. Os valores apresentados na Tabela 15 demonstram que variações nos parâmetros $Z_{a} / Z_{b}$ influenciam pouco no diagnóstico correto da RNA atuando como relé de distância no sistema elétrico em questão.

Os valores apresentados pelas 12 diferentes Tabelas desta seção, visam demonstrar a eficiência da RNA proposta na Fig. 11. Os valores de pesos e "bias" calculados pelo método de "back-propagation" são eficientes como pode-se comprovar com um índice total de acertos superior a $90 \%$.

É bem difundido na literatura que a técnica DFT de $1 / 2$ ciclo é bastante efetiva na rejeição de componentes de alta freqüência e é menos eficaz na filtragem de componentes de baixa freqüência, particularmente componentes CC [25]. Como conseqüência disto, o sobrealcance pode ocorrer com a utilização de tal filtro, em relés de distância convencionais. É mostrado, no entanto, que o esquema proposto cancela a tendência de sobrealcance do filtro, mantendo a precisão do relé como pode ser observado nas Tabelas 04,09, 14 e 15 (ângulo de incidência de falta $=0^{\circ}$ ). Além disto, 0 esquema proposto mantém a precisão do alcance para condições operacionais distintas (Tabelas 04 e 09).

Cabe salientar que o estudo levou em consideração faltas fase A-terra somente. Os mesmos pesos encontrados podem ser utilizados para o correto diagnóstico de faltas B-terra e C-terra. Com o intuito de extender o esquema proposto para situações reais, um classificador de faltas similar ao apresentado em [17] deve ser utilizado, e um processo de treinamento similar ao apresentado neste trabalho deve ser feito para outros tipos de falta. 


\begin{tabular}{|c|c|c|c|c|}
\hline Distância do ponto $\boldsymbol{A}(\mathbf{k m})$ & $\mathbf{R} \mathbf{f}=\mathbf{3} \Omega$ & $\mathbf{R} \mathbf{f}=\mathbf{1 7} \Omega$ & $\mathbf{R} \mathbf{f}=\mathbf{7 0} \Omega$ & Resposta Correta \\
\hline \hline 4 & 0 & 0 & 0 & 0 \\
\hline 15 & 0 & 0 & 0 & 0 \\
\hline 25 & 0 & 0 & 0 & 0 \\
\hline 35 & 0 & 0 & 0 & 0 \\
\hline 45 & 0 & 0 & 0 & 0 \\
\hline 55 & 0 & 0 & 0 & 0 \\
\hline 65 & 0 & 0 & 0 & 0 \\
\hline 68 & 0 & 0 & 0 & 0 \\
\hline 76 & 0 & 0 & 0 & 0 \\
\hline 79 & 0.0019 & 0.0002 & 0.0548 & 0 \\
\hline 80 & 0.9976 & 0.9998 & 0.8728 & 1 \\
\hline 82 & 1 & 1 & 0.9999 & 1 \\
\hline 84 & 1 & 1 & 1 & 1 \\
\hline 86 & 1 & 1 & 1 & 1 \\
\hline 88 & 1 & 1 & 1 & 1 \\
\hline 91 & 1 & 1 & 1 & 1 \\
\hline 93 & 1 & 1 & 1 & 1 \\
\hline 94 & 1 & 1 & 1 & 1 \\
\hline 95 & 1 & 1 & 1 & 1 \\
\hline 96 & 1 & 1 & 1 & 1 \\
\hline & & & & \\
\hline
\end{tabular}

Tabela 04-Barramento A com $1.1 \angle 15^{\circ} \mathrm{pu}$, ângulo de incidência da falta de $0^{\circ}$. Utilizada para testar a RNA da Fig. 11. 


\begin{tabular}{|c|c|c|c|c|}
\hline Distância do ponto $\mathbf{A}(\mathbf{k m})$ & $\mathbf{R f}=\mathbf{3} \Omega$ & $\mathbf{R f}=\mathbf{1 7} \Omega$ & $\mathbf{R f}=\mathbf{7 0} \Omega$ & Resposta Correta \\
\hline \hline 4 & 0 & 0 & 0 & 0 \\
\hline 15 & 0 & 0 & 0 & 0 \\
\hline 25 & 0 & 0 & 0 & 0 \\
\hline 35 & 0 & 0 & 0 & 0 \\
\hline 45 & 0 & 0 & 0 & 0 \\
\hline 55 & 0 & 0 & 0 & 0 \\
\hline 65 & 0 & 0 & 0 & 0 \\
\hline 68 & 0 & 0 & 0 & 0 \\
\hline 76 & 0.0004 & 0 & 0 & 0 \\
\hline 79 & $1 *$ & $1 *$ & 0 & 0 \\
\hline 80 & 1 & 1 & $0.0002 *$ & 1 \\
\hline 82 & 1 & 1 & 0.8317 & 1 \\
\hline 84 & 1 & 1 & 0.9999 & 1 \\
\hline 86 & 1 & 1 & 1 & 1 \\
\hline 88 & 1 & 1 & 1 & 1 \\
\hline 91 & 1 & 1 & 0.9999 & 1 \\
\hline 93 & 1 & 1 & 0.9994 & 1 \\
\hline 94 & 1 & 1 & 0.9982 & 1 \\
\hline 95 & 1 & 1 & 0.9942 & 1 \\
\hline 96 & 1 & 1 & 0.9810 & 1 \\
\hline & & & & \\
\hline
\end{tabular}

Tabela 05-Barramento A com $1.1 \angle 15^{\circ}$ pu, ângulo de incidência da falta de $30^{\circ}$. Utilizada para testar a RNA da Fig. 11 


\begin{tabular}{|c|c|c|c|c|}
\hline Distância do ponto $A(\mathrm{~km})$ & $\mathrm{Rf}=\mathbf{3} \Omega$ & $\mathrm{Rf}=17 \Omega$ & $\mathrm{Rf}=70 \Omega$ & Resposta Correta \\
\hline 4 & 0 & 0 & 0 & 0 \\
\hline 15 & 0 & 0 & 0 & 0 \\
\hline 25 & 0 & 0 & 0 & 0 \\
\hline 35 & 0 & 0 & 0 & 0 \\
\hline 45 & 0 & 0 & 0 & 0 \\
\hline 55 & 0 & 0 & 0 & 0 \\
\hline 65 & 0 & 0 & 0 & 0 \\
\hline 68 & 0 & 0 & 0 & 0 \\
\hline 76 & $0.8316^{*}$ & 0 & 0 & 0 \\
\hline 79 & $1 *$ & $1 *$ & 0 & 0 \\
\hline 80 & 1 & 1 & $0.0001 *$ & 1 \\
\hline 82 & 1 & 1 & 0.7058 & 1 \\
\hline 84 & 1 & 1 & 0.9999 & 1 \\
\hline 86 & 1 & 1 & 1 & 1 \\
\hline 88 & 1 & 1 & 1 & 1 \\
\hline 91 & 1 & 1 & 1 & 1 \\
\hline 93 & 1 & 1 & 0.9996 & 1 \\
\hline 94 & 1 & 1 & 0.9983 & 1 \\
\hline 95 & 1 & 1 & 0.9922 & 1 \\
\hline 96 & 1 & 1 & 0.9672 & 1 \\
\hline
\end{tabular}

Tabela 06-Barramento A com $1.1 \angle 15^{\circ}$ pu, ângulo de incidência da falta de $45^{\circ}$. Utilizada para testar a RNA da Fig. 11. 


\begin{tabular}{|c|c|c|c|c|}
\hline Distância do ponto $A(\mathrm{~km})$ & $\mathbf{R} f=3 \Omega$ & $\mathbf{R f}=17 \Omega$ & $\mathbf{R} f=70 \Omega$ & Resposta Correta \\
\hline 4 & 0 & 0 & 0 & 0 \\
\hline 15 & 0 & 0 & 0 & 0 \\
\hline 25 & 0 & 0 & 0 & 0 \\
\hline 35 & 0 & 0 & 0 & 0 \\
\hline 45 & 0 & 0 & 0 & 0 \\
\hline 55 & 0 & 0 & 0 & 0 \\
\hline 65 & 0 & 0 & 0 & 0 \\
\hline 68 & 0 & 0 & 0 & 0 \\
\hline 76 & 0.2167 & 0 & 0 & 0 \\
\hline 79 & $1^{*}$ & $0.9697 *$ & 0 & 0 \\
\hline 80 & 1 & 1 & $0.0003^{*}$ & 1 \\
\hline 82 & 1 & 1 & 0.9513 & 1 \\
\hline 84 & 1 & 1 & 1 & 1 \\
\hline 86 & 1 & 1 & 1 & 1 \\
\hline 88 & 1 & 1 & 1 & 1 \\
\hline 91 & 1 & 1 & 1 & 1 \\
\hline 93 & 1 & 1 & 1 & 1 \\
\hline 94 & 1 & 1 & 0.9998 & 1 \\
\hline 95 & 1 & 1 & 0.9992 & 1 \\
\hline 96 & 1 & 1 & 0.9959 & 1 \\
\hline
\end{tabular}

Tabela 07-Barramento A com $1.1 \angle 15^{\circ} \mathrm{pu}$, ângulo de incidência da falta de $60^{\circ}$. Utilizada para testar a RNA da Fig. 11. 


\begin{tabular}{|c|c|c|c|c|}
\hline Distância do ponto $A(\mathrm{~km})$ & $\mathbf{R f}=\mathbf{3} \Omega$ & $\mathbf{R f}=17 \Omega$ & $\mathbf{R f}=70 \Omega$ & Resposta Correta \\
\hline 4 & 0 & 0 & 0 & 0 \\
\hline 15 & 0 & 0 & 0 & 0 \\
\hline 25 & 0 & 0 & 0 & 0 \\
\hline 35 & 0 & 0 & 0 & 0 \\
\hline 45 & 0 & 0 & 0 & 0 \\
\hline 55 & 0 & 0 & 0 & 0 \\
\hline 65 & 0 & 0 & 0 & 0 \\
\hline 68 & 0 & 0 & 0 & 0 \\
\hline 76 & 0 & 0 & 0 & 0 \\
\hline 79 & 0.0709 & 0.0109 & 0.0742 & 0 \\
\hline 80 & 0.8522 & 0.8938 & 0.9483 & 1 \\
\hline 82 & 1 & 1 & 1 & 1 \\
\hline 84 & 1 & 1 & 1 & 1 \\
\hline 86 & 1 & 1 & 1 & 1 \\
\hline 88 & 1 & 1 & 1 & 1 \\
\hline 91 & 1 & 1 & 1 & 1 \\
\hline 93 & 1 & 1 & 1 & 1 \\
\hline 94 & 1 & 1 & 1 & 1 \\
\hline 95 & 1 & 1 & 1 & 1 \\
\hline 96 & 1 & 1 & 1 & 1 \\
\hline
\end{tabular}

Tabela 08-Barramento A com $1.1 \angle 15^{\circ}$ pu, ângulo de incidência da falta de $90^{\circ}$. Utilizada para testar a RNA da Fig. 11. 


\begin{tabular}{|c|c|c|c|c|}
\hline Distância do ponto $A(\mathrm{~km})$ & $\mathbf{R} \mathbf{f}=\mathbf{3} \Omega$ & $\mathbf{R f}=\mathbf{1 7 \Omega}$ & $\mathbf{R f}=70 \Omega$ & Resposta Correta \\
\hline 4 & 0 & 0 & 0 & 0 \\
\hline 15 & 0 & 0 & 0 & 0 \\
\hline 25 & 0 & 0 & 0 & 0 \\
\hline 35 & 0 & 0 & 0 & 0 \\
\hline 45 & 0 & 0 & 0 & 0 \\
\hline 55 & 0 & 0 & 0 & 0 \\
\hline 65 & 0 & 0 & 0 & 0 \\
\hline 68 & 0 & 0 & 0 & 0 \\
\hline 76 & 0 & 0 & 0 & 0 \\
\hline 79 & 0.0009 & 0.0272 & $0.9979 *$ & 0 \\
\hline 80 & 0.9981 & 0.9790 & 1 & 1 \\
\hline 82 & 1 & 1 & 1 & 1 \\
\hline 84 & 1 & 1 & 1 & 1 \\
\hline 86 & 1 & 1 & 1 & 1 \\
\hline 88 & 1 & 1 & 1 & 1 \\
\hline 91 & 1 & 1 & 1 & 1 \\
\hline 93 & 1 & 1 & 1 & 1 \\
\hline 94 & 1 & 1 & 1 & 1 \\
\hline 95 & 1 & 1 & 1 & 1 \\
\hline 96 & 1 & 1 & 1 & 1 \\
\hline
\end{tabular}

Tabela 09-Barramento A com 1.1 $\angle 20^{\circ}$ pu, ângulo de incidência da falta de $0^{\circ}$. Utilizada para testar a RNA da Fig. 11. 


\begin{tabular}{|c|c|c|c|c|}
\hline Distância do ponto $A(\mathrm{~km})$ & $\mathrm{Rf}=\mathbf{3 \Omega}$ & $\mathrm{Rf}=17 \Omega$ & $\mathrm{Rf}=70 \Omega$ & Resposta Correta \\
\hline 4 & 0 & 0 & 0 & 0 \\
\hline 15 & 0 & 0 & 0 & 0 \\
\hline 25 & 0 & 0 & 0 & 0 \\
\hline 35 & 0 & 0 & 0 & 0 \\
\hline 45 & 0 & 0 & 0 & 0 \\
\hline 55 & 0 & 0 & 0 & 0 \\
\hline 65 & 0 & 0 & 0 & 0 \\
\hline 68 & 0 & 0 & 0 & 0 \\
\hline 76 & 0 & 0 & 0 & 0 \\
\hline 79 & $1^{*}$ & $0.9991^{*}$ & 0 & 0 \\
\hline 80 & 1 & 1 & $0 *$ & 1 \\
\hline 82 & 1 & 1 & $0.0375 *$ & 1 \\
\hline 84 & 1 & 1 & 0.9998 & $I$ \\
\hline 86 & 1 & 1 & 1 & 1 \\
\hline 88 & 1 & 1 & 1 & 1 \\
\hline 91 & 1 & 1 & 1 & 1 \\
\hline 93 & 1 & 1 & 1 & 1 \\
\hline 94 & 1 & 1 & 1 & 1 \\
\hline 95 & 1 & 1 & 1 & 1 \\
\hline 96 & 1 & 1 & 1 & 1 \\
\hline
\end{tabular}

Tabela 10-Barramento A com $1.1 \angle 20^{\circ}$ pu, ângulo de incidência da falta de $30^{\circ}$. Utilizada para testar a RNA da Fig. 11. 


\begin{tabular}{|c|c|c|c|c|}
\hline Distância do ponto $\boldsymbol{A}(\mathbf{k m})$ & $\mathbf{R f}=\mathbf{3} \Omega$ & $\mathbf{R f}=\mathbf{1 7} \Omega$ & $\mathbf{R} \mathbf{f}=\mathbf{7 0} \Omega$ & Resposta Correta \\
\hline \hline 4 & 0 & 0 & 0 & 0 \\
\hline 15 & 0 & 0 & 0 & 0 \\
\hline 25 & 0 & 0 & 0 & 0 \\
\hline 35 & 0 & 0 & 0 & 0 \\
\hline 45 & 0 & 0 & 0 & 0 \\
\hline 55 & 0 & 0 & 0 & 0 \\
\hline 65 & 0 & 0 & 0 & 0 \\
\hline 68 & 0 & 0 & 0 & 0 \\
\hline 76 & 0 & 0.0005 & 0 & 0 \\
\hline 79 & $1^{*}$ & $1^{*}$ & 0 & 0 \\
\hline 80 & 1 & 1 & $0 *$ & 1 \\
\hline 82 & 1 & 1 & $0 *$ & 1 \\
\hline 84 & 1 & 1 & $0.2313^{*}$ & 1 \\
\hline 86 & 1 & 1 & 1 & 1 \\
\hline 88 & 1 & 1 & 1 & 1 \\
\hline 91 & 1 & 1 & 1 & 1 \\
\hline 93 & 1 & 1 & 1 & 1 \\
\hline 94 & 1 & 1 & 1 & 1 \\
\hline 95 & 1 & 1 & 1 & 1 \\
\hline 96 & 1 & 1 & 1 & 1 \\
\hline & & & & \\
\hline & 1 & 1 & 1 & 0 \\
\hline
\end{tabular}

Tabela 11-Barramento A com $1.1 \angle 20^{\circ}$ pu, ângulo de incidência da falta de $45^{\circ}$. Utilizada para testar a RNA da Fig. 11. 


\begin{tabular}{|c|c|c|c|c|}
\hline Distância do ponto $\boldsymbol{A}(\mathrm{km})$ & $\mathbf{R f}=\mathbf{3} \Omega$ & $\mathbf{R f}=\mathbf{1 7} \Omega$ & $\mathbf{R f}=\mathbf{7 0} \Omega$ & Resposta Correta \\
\hline \hline 4 & 0 & 0 & 0 & 0 \\
\hline 15 & 0 & 0 & 0 & 0 \\
\hline 25 & 0 & 0 & 0 & 0 \\
\hline 35 & 0 & 0 & 0 & 0 \\
\hline 45 & 0 & 0 & 0 & 0 \\
\hline 55 & 0 & 0 & 0 & 0 \\
\hline 65 & 0 & 0 & 0 & 0 \\
\hline 68 & 0 & 0 & 0 & 0 \\
\hline 76 & $0.9970^{*}$ & $0.8599^{*}$ & 0 & 0 \\
\hline 79 & $1 *$ & $1 *$ & 0 & 0 \\
\hline 80 & 1 & 1 & $0 *$ & 1 \\
\hline 82 & 1 & 1 & $0 *$ & 1 \\
\hline 84 & 1 & 1 & $0.3297^{*}$ & 1 \\
\hline 86 & 1 & 1 & 1 & 1 \\
\hline 88 & 1 & 1 & 1 & 1 \\
\hline 91 & 1 & 1 & 1 & 1 \\
\hline 93 & 1 & 1 & 1 & 1 \\
\hline 94 & 1 & 1 & 1 & 1 \\
\hline 95 & 1 & 1 & 1 & 1 \\
\hline 96 & 1 & 1 & 1 & 1 \\
\hline
\end{tabular}

Tabela 12-Barramento A com $1.1 \angle 20^{\circ}$ pu, ângulo de incidência da falta de $60^{\circ}$.

Utilizada para testar a RNA da Fig. 11. 


\begin{tabular}{|c|c|c|c|c|}
\hline Distância do ponto $A(\mathrm{~km})$ & $\mathrm{Rf}=\mathbf{3 \Omega}$ & $\mathrm{Rf}=17 \Omega$ & $\mathbf{R f}=70 \Omega$ & Resposta Correta \\
\hline 4 & 0 & 0 & 0 & 0 \\
\hline 15 & 0 & 0 & 0 & 0 \\
\hline 25 & 0 & 0 & 0 & 0 \\
\hline 35 & 0 & 0 & 0 & 0 \\
\hline 45 & 0 & 0 & 0 & 0 \\
\hline 55 & 0 & 0 & 0 & 0 \\
\hline 65 & 0 & 0 & 0 & 0 \\
\hline 68 & 0 & 0 & 0 & 0 \\
\hline 76 & 0 & 0 & 0 & 0 \\
\hline 79 & 0 & 0.1206 & 0.2374 & 0 \\
\hline 80 & 1 & 1 & 0.7511 & 1 \\
\hline 82 & 1 & 1 & 0.9921 & 1 \\
\hline 84 & 1 & 1 & 0.9997 & 1 \\
\hline 86 & 1 & 1 & 1 & 1 \\
\hline 88 & 1 & 1 & 1 & 1 \\
\hline 91 & 1 & 1 & 1 & 1 \\
\hline 93 & 1 & 1 & 1 & $I$ \\
\hline 94 & 1 & 1 & 1 & 1 \\
\hline 95 & 1 & 1 & 1 & 1 \\
\hline 96 & 1 & 1 & 1 & 1 \\
\hline
\end{tabular}

Tabela 13-Barramento A com $1.1 \angle 20^{\circ}$ pu, ângulo de incidência da falta de $90^{\circ}$. Utilizada para testar a RNA da Figura 11. 


\begin{tabular}{|c|c|c|c|c|c|}
\hline \multirow[t]{2}{*}{ Distância do ponto $A(\mathrm{~km})$} & \multicolumn{4}{|c|}{$\begin{array}{l}\text { Resposta da RNA para a capacidade } \\
\text { da Fonte A de: }\end{array}$} & \multirow[t]{2}{*}{ Resposta Correta } \\
\hline & 6GVA & 8GVA & 12GVA & 14GVA & \\
\hline 4 & 0 & 0 & 0 & 0 & 0 \\
\hline 15 & 0 & 0 & 0 & 0 & 0 \\
\hline 25 & 0 & 0 & 0 & 0 & 0 \\
\hline 35 & 0 & 0 & 0 & 0 & 0 \\
\hline 45 & 0 & 0 & 0 & 0 & 0 \\
\hline 55 & 0 & 0 & 0 & 0 & 0 \\
\hline 65 & 0 & 0 & 0 & 0 & 0 \\
\hline 68 & 0 & 0 & 0 & 0 & 0 \\
\hline 76 & 0 & 0 & 0 & 0 & 0 \\
\hline 79 & 0 & $0.0186^{*}$ & 0.0014 & 0 & 0 \\
\hline 80 & $0.0001 *$ & 0.9743 & 0.8601 & $0.3209^{*}$ & 1 \\
\hline 82 & 0.9989 & 1 & 1 & 1 & 1 \\
\hline 84 & 1 & 1 & 1 & 1 & 1 \\
\hline 86 & 1 & 1 & 1 & 1 & 1 \\
\hline 88 & 1 & 1 & 1 & 1 & 1 \\
\hline 91 & 1 & 1 & 1 & 1 & 1 \\
\hline 93 & 1 & 1 & 1 & 1 & 1 \\
\hline 94 & 1 & 1 & 1 & 1 & 1 \\
\hline 95 & 1 & 1 & 1 & 1 & 1 \\
\hline 96 & 1 & 1 & 1 & 1 & 1 \\
\hline
\end{tabular}

Tabela 14-Barramento A com $1.1 \angle 20^{\circ} \mathrm{pu}$, ângulo de incidência da falta de $0^{\circ}$.

Variação na capacidade da fonte A. Utilizada para testar a RNA da Fig. 11. 


\begin{tabular}{|c|c|c|c|c|}
\hline Distância do ponto $\boldsymbol{A}(\mathrm{km})$ & $\mathbf{Z}_{\mathrm{a}} / \mathbf{Z}_{\mathbf{b}}=\mathbf{1 0}$ & $\mathbf{Z}_{\mathrm{a}} / \mathbf{Z}_{\mathrm{b}}=\mathbf{5 0}$ & $\mathbf{Z}_{\mathrm{a}} / \mathbf{Z}_{\mathbf{b}}=\mathbf{9 0}$ & Resposta Correta \\
\hline \hline 4 & 0 & 0 & 0 & 0 \\
\hline 15 & 0 & 0 & 0 & 0 \\
\hline 25 & 0 & 0 & 0 & 0 \\
\hline 35 & 0 & 0 & 0 & 0 \\
\hline 45 & 0 & 0 & 0 & 0 \\
\hline 55 & 0 & 0 & 0 & 0 \\
\hline 65 & 0 & 0 & 0 & 0 \\
\hline 68 & 0 & 0 & 0 & 0 \\
\hline 76 & 0 & $0.9984^{*}$ & $0.9979^{*}$ & 0 \\
\hline 79 & 0.0037 & $1^{*}$ & $1^{*}$ & 0 \\
\hline 80 & 0.9209 & 1 & 1 & 1 \\
\hline 82 & 1 & 1 & 1 & 1 \\
\hline 84 & 1 & 1 & 1 & 1 \\
\hline 86 & 1 & 1 & 1 & 1 \\
\hline 88 & 1 & 1 & 1 & 1 \\
\hline 91 & 1 & 1 & 1 & 1 \\
\hline 93 & 1 & 1 & 1 & 1 \\
\hline 94 & 1 & 1 & 1 & $I$ \\
\hline 95 & 1 & 1 & 1 & 1 \\
\hline 96 & 1 & 1 & 1 & 1 \\
\hline
\end{tabular}

Tabela 15-Barramento A com 1.1 $\angle 20^{\circ}$ pu, ângulo de incidência da falta de $0^{\circ}$. Modificações nos parâmetros $Z_{d} Z_{b}$. Utilizada para testar a RNA da Fig. 11 . 


\section{5-CONCLUSÃO}

Os resultados obtidos neste trabalho apontam para um excelente desempenho na utilização de Redes Neurais Artificiais operando como relés de distância em um Sistema Elétrico de Potência. Apesar das dificuldades presentes na utilização da técnica de Redes Neurais Artificiais tais como: a necessidade de testar diversas arquiteturas de Redes Neurais Artificiais, até a obtenção de uma com resultados satisfatórios; o elevado tempo gasto para a convergência dos valores; a necessidade de inúmeros padrões para serem utilizados no treinamento da Rede Neural Artificial, entre outros, o desempenho apresentado justifica este esforço. As diversas técnicas de Redes Neurais Artificiais se encontram em uma evolução acelerada, com o surgimento de novas rotinas a cada momento, mais rápidas e mais precisas, possibilitando assim uma maior facilidade na aplicação de Redes Neurais Artificiais em estudos mais recentes.

Com as diferentes arquiteturas de Redes Neurais Artificiais utilizadas neste estudo, cabe destacar a relação entre a quantidade de simulações necessárias para o treinamento e o número de parâmetros a serem variados na Linha de Transmissão. A medida que a simulação da Linha de Transmissão se aproxima de um modelo real, o número de padrões necessários para sua correta representação aumenta.

Os resultados obtidos com os testes, utilizando os pesos calculados para as diferentes arquiteturas de Redes Neurais Artificiais, foram excelentes. O reconhecimento de padrão é notado pela qualidade das respostas, mediante diversas situações inéditas 
testadas. Mais de $90 \%$ das respostas obtidas pelos testes foram corretas e mesmo os valores incorretamente apontados ocorreram dentro de uma estreita faixa, que pode ser considerada como uma região de indeterminação (próxima a região de mudança do estado do relé). Fica então bastante claro com os resultados apresentados que o relé considerado pode prover uma operação rápida e segura, mantendo a precisão de seu alcance quando sujeito a diferentes condições de falta (mesmo na presença do componente $\mathrm{CC}$ na corrente) e mudanças na rede. Este é um bom desempenho apresentado, sob as limitações destas simulações, se comparado aos relés de distância convencionais. Assim, o uso de relés baseados em Redes Neurais Artificiais pode trazer a possibilidade da extensão da primeira zona de alcance dos relés, melhorando a segurança dos sistemas.

Mesmo levando-se em consideração as limitações citadas anteriormente, deve ser enfatizado que esta ferramenta abre uma nova dimensão na filosofia de relés, permitindo a resolução de vários problemas relacionados a proteção de Linhas de Transmissão. 


\section{ANEXO - Publicações Provenientes deste Trabalho}

- $13^{\text {TH }}$ International Conference SMiRT - The Application of Intelligent Software System in Power Plant, Process Plant and Structural Engineering Título do trabalho - "Artificial Neural Networks Applied to Protection of Power Plant" Autores: David Calhau Jorge e Prof. Dr. Denis Vinícius Coury Período - 21 a 23 de agosto de $1995 \quad$ Local - São Paulo - S.P.

- 1997 International Conference on Neural Networks (ICNN'97/IEEE)

Título do trabalho - "The Back-propagation Algorithm Applied to Protective Relaying" Autores: David Calhau Jorge e Prof. Dr. Denis Vinícius Coury Período - 09 a 12 de junho de $1997 \quad$ Local - Houston - Texas - EUA

- PES-IEEE Transactions (no prelo)

Título do trabalho - "Artificial Neural Network Approach to Distance Protection of Transmission Lines"

Autores: David Calhau Jorge e Prof. Dr. Denis Vinícius Coury 


\section{REFERÊNCIAS BIBLIOGRÁFICAS}

[1]Caminha, A. C. - "Introdução à proteção dos sistemas elétricos", São Paulo, Ed. Edgard Blücher LTDA - 1977.

[2]Phadke, A. G.; Thorp, J. S. - "Computer relaying for power systems", Reino Unido, Ed. John Wiley and Sons - 1988.

[3]Sakaguchi, T.; Matsumoto, K. - "Development of a based system for power system restoration" - IEEE Transactions on Power Apparatus and Systems, Vol. PAS 102 1983.

[4]Talukdar, S. N.; Cardozo, E.; Perry, T. - "The operator's assistant--an inteligent, expandable program for Power System Trouble Analysis" - IEEE Transactions on Power Systems, Vol. PWRS-1, No. 3 - 1986.

[5]Kukui, C.; Kawakami, J. - “An expert system for fault section estimation using information from protective relays and circuit breakers" - IEEE Transactions on Power Delivery, Vol. PWRD-1, No.4 - 1986. 
[6]Kezunovic, M. et al. - "An expert system for transmission substation event analysis" - IEEE Transactions on Power Delivery, Vol. 8, No. 4 - 1993.

[7]Sharkawi, M. A. El; et al. - "Neural Networks and their application to Power Engineering" - 1991 "Control and Dynamics Systems" vol. 41. - Ed. Academic Press Inc., p.359-451 - 1994.

[8]Kanoh, H.; et al. - "Fault location for Transmissions Lines using Inference Model Neural Network" - Electrical Engineer in Japan - 1990.

[9]Chakravarthy, S. K.; et al. - "Applying pattern recognition in distance relaying Part 1 :Concept"- IEE Proceedings-C, Vol. 139, No.4 - 1992.

[10]Chakravarthy, S. K.; et al. - "Applying pattern recognition in distance relaying Part 2:Feasibility"- IEE Proceedings-C, Vol. 139, No.4 - 1992.

[11]Swarup,K.S.; Chandrasekharaiah, H.S. - "Fault detection and diagnosis of Power Systems using Artificial Neural Networks", First International Forum on Applications of Neural Networks to Power Systems, Seattle - Estados Unidos da América, 23-26 de Julho, p.102-106 - 1991.

[12]Cen, W.; et al. - "Power System Fault Diagnosis Based on a New Feed Forward Neural Networks"- International Power Engineer Conference 1993, p.761-65 - 1993. 
[13]Silva, A.P. A.; et al. - "Neural Networks for Fault Location in Substations" - IEEE Transactions on Power Delivery, Vol. 11, No. 1 - 1996.

[14]Khaparde, S.A.; Kale, P.B.; Agarwal, S.H. - "Application of Artificial Neural Network in Protective Relaying of Transmission Lines", First International Forum on Applications of Neural Networks to Power Systems, Seattle - Estados Unidos da América, 23-26 de Julho, p.139-143 - 1991.

[15] Aggarwal, R. K.; et al. - "Design and implementation of an adaptive single pole autoreclosure technique for Transmission Lines using Artificial Neural Networks" IEEE Transactions on Power Delivery, Vol.11, No.2 - 1996.

[16]Aggarwal, R.K. - "A novel technique for phase selection based on fault generated high frequency noise using Neural Networks" - Notas de Aula do Curso Ministrado na EESC-USP - 1995.

[17]Dalstein, T.; Kulicke, B. - "Neural Network approach to fault classification for high speed protective relaying" - IEEE Transactions on Power Delivery, Vol. 10, No. 2 $-1995$.

[18]Sidhu, T. S.; Singh, H.; Sachdev, M.S. - "Design, implementation and testing of an Artificial Neural Network based fault direction discriminator for protecting Transmission Lines" - IEEE Transactions on Power Delivery, Vol. 10, No. 2 - 1995. 
[19]Dalstein, T.; et al. - "Multi Neural based fault area estimation for high speed protective relaying" - IEEE Transactions on Power Delivery, Vol.11, No.2 - 1996.

[20]Silva, C. da Jr.; Sasson, S. - "Biologia 1-Citologia-Histologia”, 5.ed. São Paulo, Ed. Atual, Cap.21, p.262-269 - 1994.

[21]Rich, E.; Knight, K. - "Inteligência Artificial", 2.ed., São Paulo, Ed. Makron Books, Cap.18, p.562-568 - 1993.

[22]Hertz, J.; Krogh, A.; Palmer, R. G. - "Introduction to the theory of neural computation", Estados Unidos da América, Ed. Addison-Wesley Publishing - 1991.

[23]Demuth, H.; Beale, M. - "Neural Network-Toolbox-for use with Matlab" ${ }^{\text {"k" - }}$ Mamual, Estados Unidos da América, Ed. Math Works Inc. - 1992.

[24]Jonhs, A.T.; Aggarwal, R.K. - "Simulation of faulted EHV Transmission Lines with particular reference to very high speed protection", IEE Proceeding, Vol. 123 1976.

[25]Altuve, H.J.; Diaz, I.; Vasquez, E. - "Fourier and Walsh digital filtering algorithms for Distance Protection", IEEE Transactions on Power Systems, Vol. 11, No. 2 - 1995 


\section{APÊNDICE I}

Programa para Simulação de Linhas de Transmissão em Condições Faltosas TEER

Existe um alto índice de complexidade que envolve o comportamento de uma LT em uma situação faltosa. A maioria das simulações envolvendo sistemas elétricos de potência é obtida através de equacionamento matemático das LT's e seus componentes. A presença de muitos parâmetros, assim como um comportamento de dificil equacionamento, fazem com que a obtenção de dados referentes as LT's faltosas deva ser calculada com programas computacionais específicos para este propósito. Foi utilizado um programa computacional para obter os resultados referentes aos parâmetros da Linha de Transmissão, para o estudo em questão, durante uma falta. O programa simulador de situações faltosas em um circuito elétrico é conhecido por "TEER", e foi desenvolvido por Agarwall, R.K.; et.al [24]. A eficiência deste programa foi comprovada após diversos testes, realizados por seus autores, durante seu desenvolvimento, estando estes testes devidamente documentados. A forma de entrada de dados, simples e prática, e a comprovada eficiência do método utilizado foram os principais motivos para utilizálo como gerador dos dados para os estudos envolvendo RNA's para proteção de Sistemas Elétricos de Potência. Este programa utiliza como configuração básica o circuito mostrado na Fig. I.1. 


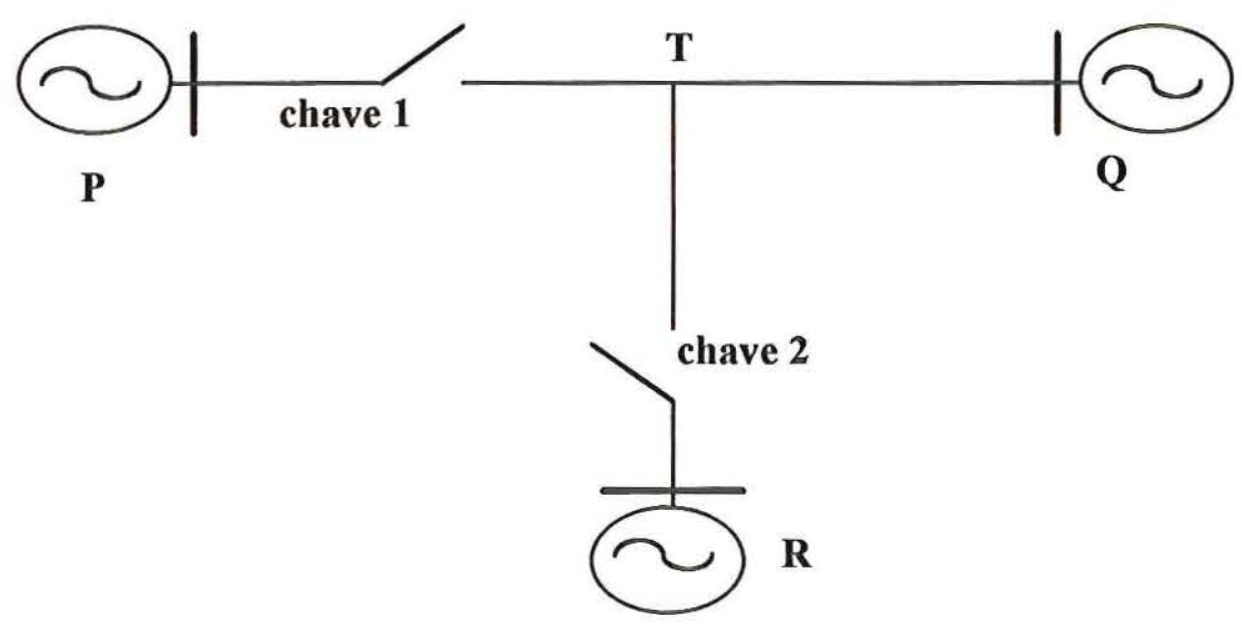

Figura I.1 - Diagrama do circuito utilizado para análise pelo programa "TEER".

O diagrama elétrico da Fig. I.1 apresenta três fontes geradoras $\mathrm{P}, \mathrm{Q}$ e $\mathrm{R}$ trifásicas. O valor de cada fonte, assim como seus parâmetros são definidos pelo usuário na entrada de dados do programa. A distância entre as fontes pode ser definida de acordo com a LT que se deseja simular. Entre os pontos $\mathrm{P}$ e $\mathrm{Q}$ existe um ponto $\mathrm{T}$ onde ocorre uma conexão com a terceira fonte R. Este tipo de ligação é conhecido por configuração "T" de uma LT. A forma da Linha de Transmissão pode ser modificada de acordo com a situação de duas chaves, indicadas como chave 1 e 2 na Fig. I.1. Estas chaves visam escolher configurações da linha com dois terminais ou três terminais. Após a definição da arquitetura da Linha de Transmissão é permitido ao usuário configurar os parâmetros da Linha de Transmissão a ser estudada de forma minuciosa; entre estes parâmetros:

- A capacidade e característica das fontes do circuito e parâmetros internos a estas. 
- As características da falta, tais como: tipo de falta, resistência de falta, localização da mesma ao longo da linha, ângulo de incidência da falta com relação a tensão, entre outros.

- A quantidade de ciclos a serem observados no pré-falta e no pós-falta, assim como a taxa amostral utilizada.

Diversos outros parâmetros podem ser indicados no programa, tais como configuração dos cabos elétricos da Linha de Transmissão, parâmetros físicos da Linha de Transmissão, etc.

Para todas as simulações utilizadas, a configuração adotada para o circuito elétrico mantinha a chave 2 aberta. Foram realizadas mais de 3000 simulações utilizando-se este programa. Os parâmetros que sofreram variações, durante as simulações, foram a distância de falta, resistência de falta, ângulo de incidência da falta e capacidade e característica das fontes $\mathrm{P}$ e Q e fluxo de carga na linha. Os parâmetros físicos da LT foram mantidos constantes, supondo uma única LT durante todas as simulações.

O programa apresenta como resultados os valores de tensão e corrente de pré e pós falta no intervalo escolhido e na taxa amostral definidos pelo usuário.

Este programa foi utilizado visando obter apenas os valores de tensão e corrente de pré-falta e pós-falta. É possível através destes valores definir o comportamento de uma LT em uma situação faltosa, e possibilitar a simulação de um relé de distância.

As Figuras I.2 e I.3 apresentam um exemplo da forma de onda de tensão e corrente encontradas em uma LT da Fig. 08 simulada no "TEER". Pode-se observar nos gráficos a presença de um ângulo de incidência da falta de $90^{\circ}$. O valor de tensão utilizado no circuito trifásico é de $400 \mathrm{kV}$, com uma freqüência de $60 \mathrm{~Hz}$. Para as 
simulações apresentadas nas duas Figuras foi utilizada uma taxa amostral de $4 \mathrm{kHz}$, obtendo-se um total de aproximadamente 67 amostras de tensão e corrente por ciclo.

Os valores fornecidos pelo "TEER" são apenas a seqüência numérica, através de colunas, dos valores de tensão e corrente de cada fase calculados. A obtenção dos gráficos apresentados nas Figuras I.2 e I.3 foi realizada através da utilização de um programa específico para geração de gráficos científicos.

Alguns parâmetros fundamentais da LT, utilizados nas simulações foram:

(i) Resistividade da terra (assumida homogênea) $100 \Omega \mathrm{m}$

(ii) Com relação as fontes:

razão $\mathrm{X} / \mathrm{R}=10$

razão das impedâncias de seqüência $Z_{S 0} / Z_{S 1}=1.5$

(iii) Condutores de fase $=4 \times 54 / 7 / 0.33$ s.c.a.

condutor terra $=54 / 7 / 0.33$ s.c.a.

(iv) Razões dos TC's e TP's=400/0.11 e 2000/1 respectivamente. 


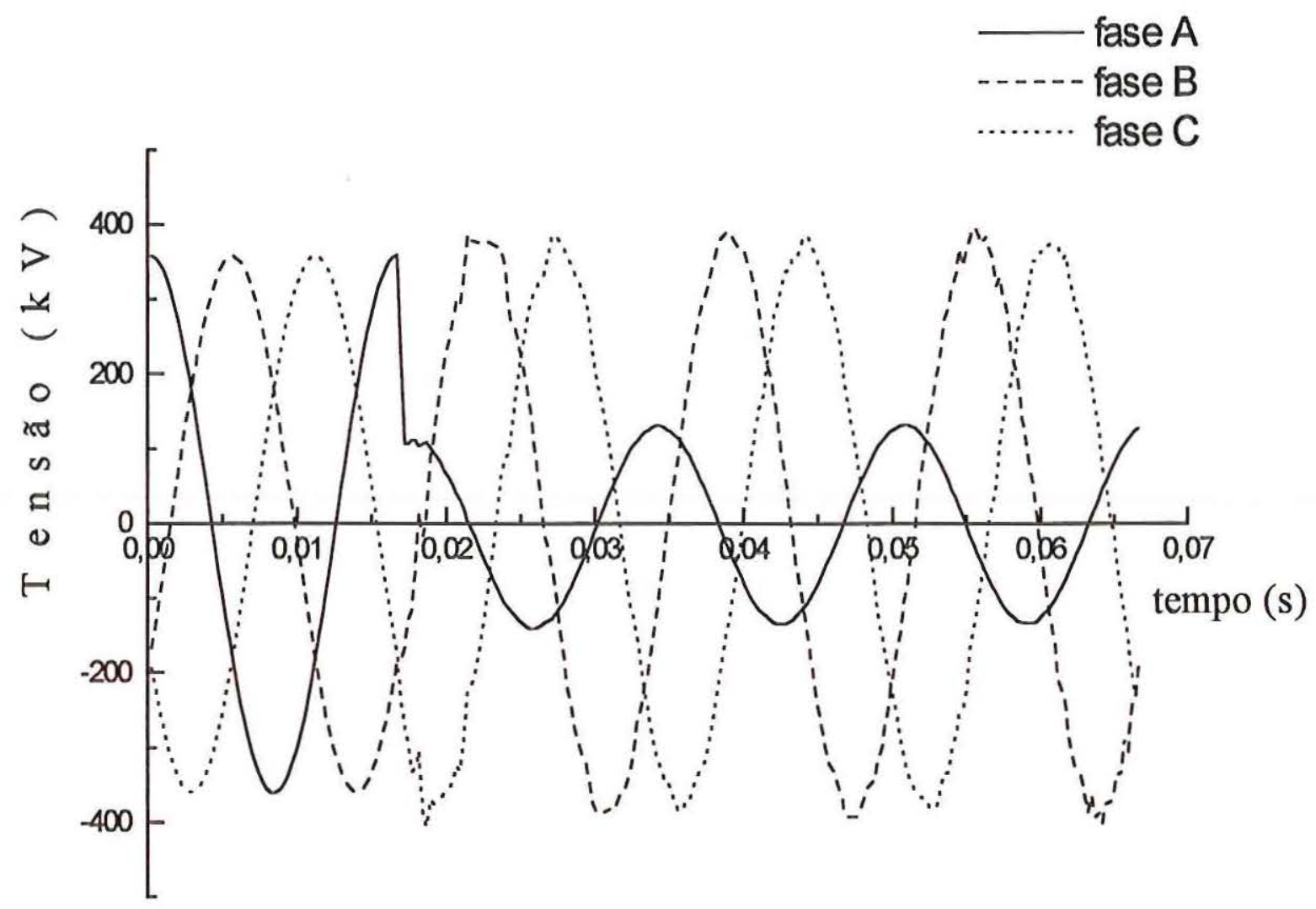

Figura I.2 - Formas de onda das três fases da tensão, formadas a partir de valores fornecidos pelo programa "TEER". 


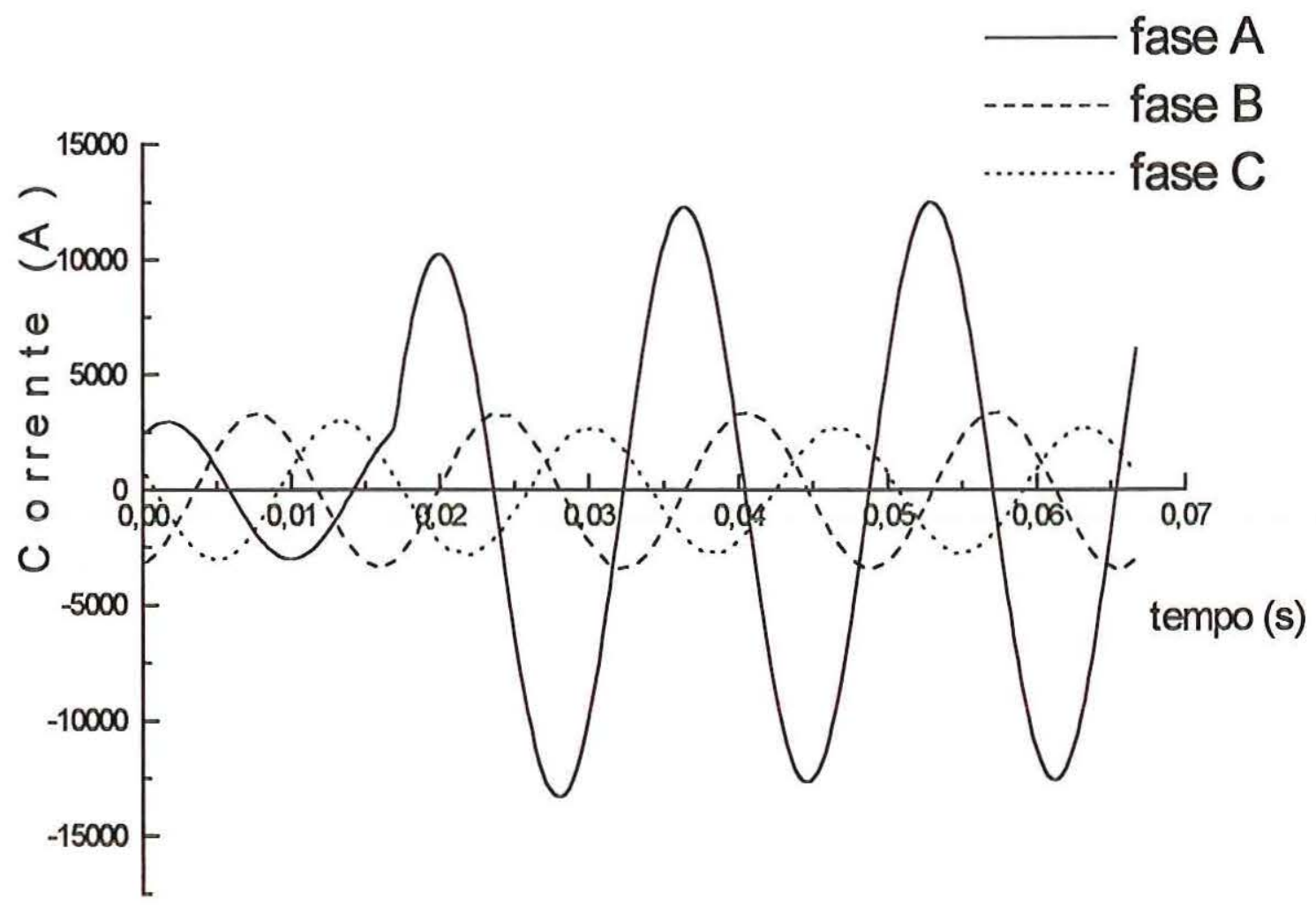

Figura I.3 - Formas de onda das três fases da corrente, formadas a partir de valores fornecidos pelo programa "TEER". 


\section{APÊNDICE II}

\section{Transformada Discreta de Fourier}

A forma do sinal da corrente ou da tensão de um circuito elétrico é essencialmente senoidal. As fontes geradoras de um circuito elétrico operam a uma freqüência de $50 \mathrm{~Hz}$ ou $60 \mathrm{~Hz}$. No Brasil a freqüência de operação é de $60 \mathrm{~Hz}$. No entanto, durante uma situação em que ocorre uma falta em um circuito elétrico a presença de inversores, transformadores, conversores e cargas entre outros dispositivos ocasionam o surgimento de distorções harmônicas no sinal, e de uma componente CC (corrente contínua). Como para a maioria das análises envolvendo o circuito elétrico a principal informação necessária são os valores de tensão e corrente na freqüência fundamental $(50 \mathrm{~Hz}$ ou $60 \mathrm{~Hz})$, torna-se imprescindivel a filtragem dos dados de forma a se obter apenas os valores nesta freqüência.

Visando obter os valores numéricos na freqüência fundamental foram desenvolvidos programas cuja finalidades seriam: a aquisição de dados, fornecidos pelo

programa TEER (Apêndice I), utilizado como simulador das faltas na Linha de Transmissão, seguida da aplicação da técnica da Transformada Discreta de Fourier. Os programas para este fim foram desenvolvidos em linguagem Pascal.

A Fig. II.1 apresenta o sinal da tensão elétrica de uma fase, com um ciclo de préfalta e um ciclo de pós-falta. Pode-se observar na Fig. II.1 o sinal sem a filtragem dos 
valores e o sinal com os valores filtrados. Pode-se notar a diferença existente entre as duas situações (sinal filtrado e não filtrado), apontando a necessidade de filtragem do sinal eliminando assim o ruído presente no mesmo.

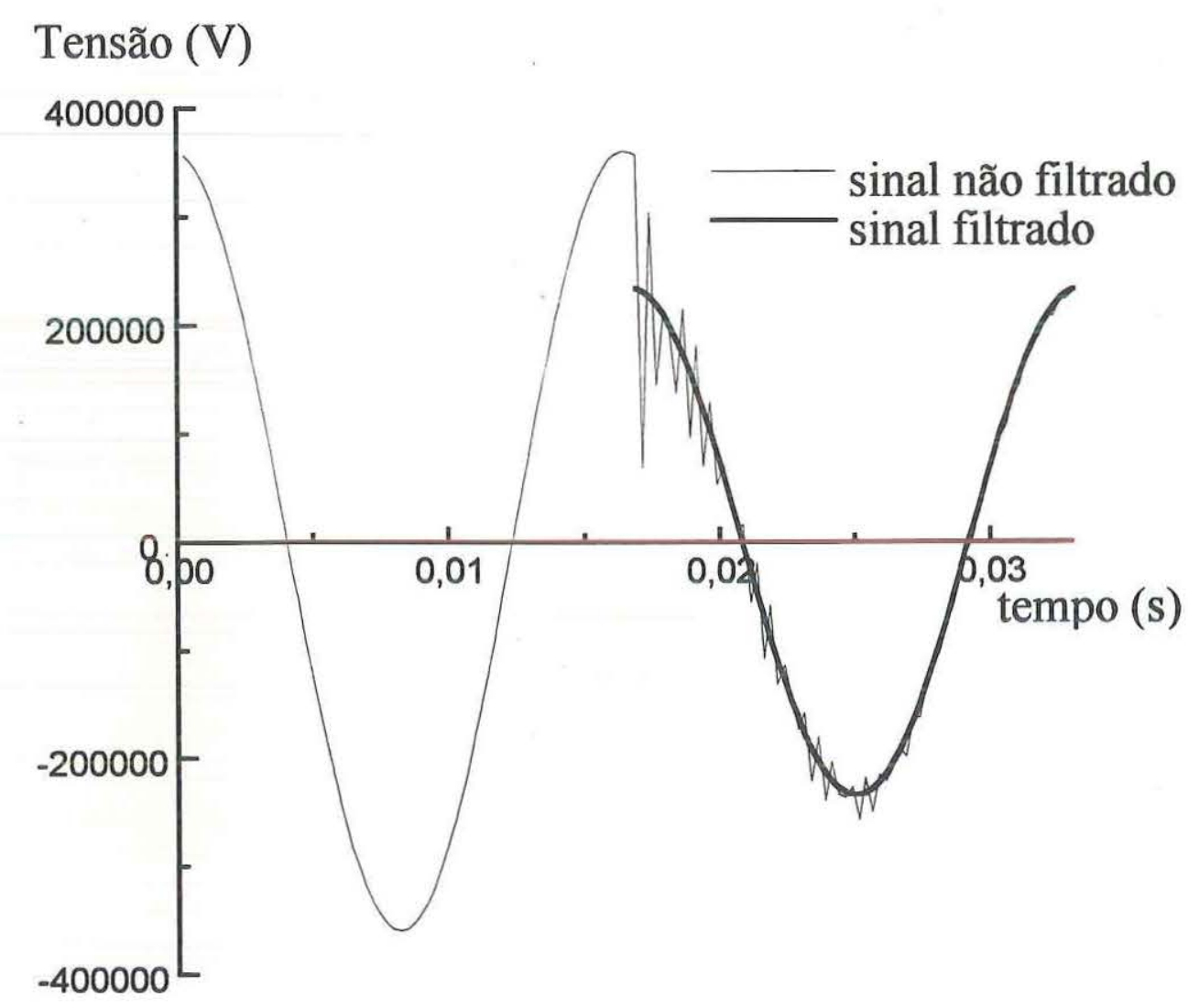

Figura II.1 - Valores obtidos pelo programa "TEER" e posteriormente filtrados utilizando-se DFT de $1 / 2$ ciclo.

O método utilizado para filtragem do sinal é baseado em aplicações das propriedades que envolvem as séries de Fourier, cuja técnica de implementação permite analisar sinais periódicos e não periódicos, mediante a transformação destes sinais em uma série seqüencial de números. A aplicação destas propriedades resultam na 
implementação matemática das Transformadas de Fourier, cuja finalidade é a análise de sinais, contínuos ou discretos no domínio da freqüência. O equacionamento aplicado para a obtenção da transformada de Fourier pode ser observado em (1).

$$
X(\omega)=\sum_{n=0}^{k} x_{n} e^{-j z \omega k n}
$$

Em (1) temos:

$\mathrm{z}=0.507$, é uma constante que depende do número de ciclos utilizados para a filtragem, seu valor é 1 se for um ciclo e 0.507 se for $1 / 2$ ciclo; $\omega=2 \pi f$, sendo $\mathrm{f}$ a freqüência;

k é o número total de dados;

n é o número do dado correspondente;

$\mathrm{x}_{\mathrm{n}}$ é o valor numérico do n'ésimo dado e $\mathrm{X}$ o valor da transformada nesta freqüência calculada. 